\title{
EL "INTERCAMBIO DE LAS PRINCESAS": ARTE Y POLÍTICA EN LAS FIESTAS DE LA BODA ENTRE FERNANDO DE BORBÓN Y BÁRBARA DE BRAGANZA
}

\author{
António Filipe Pimentel \\ Universidade de Coimbra
}

\begin{abstract}
RESUMEN
El inusual episodio del intercambio de princesas que, en enero de 1729, reunió en la frontera de Caya, entre Elvas y Badajoz, a las dos cortes ibéricas, fue un espectáculo sin precedentes en cuanto a pompa y emulación mutua, que si bien ha despertado mucho interés tanto por parte de la historiografía como por parte de la historiografía del arte de ambos países, no suscitó una comparación crítica por parte de ninguna de las dos disciplinas. El presente artículo profundizará en muchos de estos aspectos a lo que se suma la luz que aporta nueva e importante documentación.
\end{abstract}

Palabras clave: António Canevari, Barroco, Arquitectura efímera, Fiesta, Intercambio de princesas, Caya

\begin{abstract}
The unusual exchange of princesses that, in January 1729, brought the two Iberian courts together at the border at Caia, between Elvas and Badajoz, was unprecedented in terms of pomp and the desire of both parties to outdo each other. Although it has aroused great interest among historians and art historians in both countries, the event has not been subject to a critical comparison by either discipline. This article will analyse many of these aspects in depth and will also shed new light provided by important and hitherto unseen documents.
\end{abstract}

Keywords: Antonio Canevari, Baroque, ephemeral architecture, celebration, exchange of princesses, Caia

Movidas por el insólito aparato, a un tiempo diplomático y ceremonial (con las inherentes consecuencias estéticas) que, en enero de 1729, rodeó, en la frontera luso-española del Caya, entre Elvas y Badajoz, al denominado intercambio de las princesas (de las infantas Bárbara de Braganza y Mariana Victoria de Borbón, hijas de D. Juan $V$ de Portugal y de Felipe $V$ de España, destinadas a casarse con los herederos de los reinos vecinos: el Príncipe de Asturias, Fernando de Borbón, y el Príncipe del Brasil, D. José de Braganza), tanto la historiografía como la historiografía artística de ambos países hace mucho que se interesan por esta cuestión, acumulando, de esta manera, amplia información. A pesar de ello, la atávica tendencia de los investigadores de ambas áreas (Historia e Historia del Arte) al aislamiento de las respectivas investiga- ciones, así como el surgimiento de nuevos elementos, parece justificar una revisión de este viejo tema, de cara a cruzar los datos suministrados por las dos plataformas de observación y estudio, así como a incorporar los nuevos eslabones, obteniendo así una visión integrada de un proceso que, desde cualquiera de sus ángulos, reviste un incuestionable interés: cada uno de ellos se revela útil para el conocimiento de los datos aportados por el otro.

La propuesta del doble matrimonio de los herederos a los tronos peninsulares partiría de los monarcas españoles hacia sus pares portugueses - y el hecho es relevante- en marzo de 1725, tras el dramático repudio, por iniciativa del nuevo jefe del gobierno francés, el Duque de Borbón, de Mariana Victoria (Mariannina), que residía en Versalles desde 1722 , destinada 
a contraer matrimonio con el joven Luis $\mathrm{XV}^{1}$. Mariana había partido por aquel entonces, en enero, sin haber cumplido los cuatro años, para ser intercambiada en la Isla de los Faisanes, en el río Bidasoa y entre alardes de pompa, por Mademoiselle de Montpensier, Luisa Isabel de Orleáns, hija del Regente francés y destinada a contraer matrimonio con el hermano de Mariana, el efímero rey Luis $\mathrm{I}^{2}$ : fue coronado ante la abdicación, dos años más tarde, de Felipe $\mathrm{V}$, quien, ocho meses después, hubo de regresar al trono a causa de la muerte de Luis. En ese momento Mariana contaba siete años, Don José, su putativo prometido, once y Fernando y Bárbara, respectivamente, doce y catorce.

El programa de la doble alianza en la Casa de Braganza se inscribe, por lo tanto, directamente, en el marco genérico de la consabida y compleja estrategia matrimonial permanentemente desarrollada por su madre, Isabel de Farnesio y, de modo particular, en el de la urgente reparación de la afrenta sufrida por la juvenil princesa: y, de forma indirecta, por la Monarquía castellana. Casar rápidamente a la repudiada infantita en un trono mínimamente lustroso - y el del portugués de Don Juan $\mathrm{V}$ así lo era- sería el motor central del doble enlace: el de Fernando (el hijastro) y Bárbara dejaba, indirectamente, libres para los infantes, hijos de la Reina, otros partidos europeos más lustrosos: como escribiría Alfonso Danvila:

Tales fureron los célebres matrimonios portugueses que tanto dieron que hablar y tantas interrupciones y contrariedades sufrieron hasta celebrarse. Ninguna ventaja conseguimos con ellos, como no fuera el hacer ceñir una corona á la Infanta desairada por Luís XV. El príncipe Fernando fué sacrificado con ellos ${ }^{3}$.

No obstante, desde el punto de vista portugués la propuesta significaba igualmente una oportunidad: no tanto en cuanto a apaciguar viejas cuestiones que, desde el Tratado de Utrecht, minaban las relaciones de los dos países y habían llegado a dictar preparativos bélicos (en esencia, el pago, nunca efectuado, de la indemnización a la que España había sido condenada tras la Guerra de Sucesión y la delimita- ción, siempre pendiente, de las fronteras de los dominios ibéricos en América del Sur, lo que implicaba la devolución por España de la colonia de Sacramento), sino porque Portugal se consideraba igualmente ofendido con la nación gala, a partir del episodio de la exclusión portuguesa del Congreso de Cambrai, en 1720, envenenada por otro episodio protocolario (aunque no inocente) que había conducido a la retirada de Lisboa del abad Livry, ministro de Luis $X V$, precisamente en enero de $1725^{4}$. Y a todo esto añadiría, en realidad, el honor que representaba la perspectiva de ver sentarse a Bárbara en uno de los tronos de mayor relevancia entre las potencias católicas de primera grandeza.

La propuesta resultaría acogida, por lo tanto, con claro entusiasmo por parte del Rey de Portugal, a fin de evitar complicaciones posteriores a causa de condicionantes que, desde el principio, desvirtuarían la correspondiente negociación: básicamente, la constitución paralela de una alianza ofensiva y defensiva ${ }^{5}$, entre las dos Coronas, para evitar arrastrar a la Monarquía portuguesa hacia el auténtico avispero en que, por aquel entonces, se había convertido buena parte de Europa, y donde las ambiciones de la Reina de España de obtener coronas para sus restantes hijos ocupaban una parte sustancial. Este propósito chocaba con la inamovible neutralidad asumida por Don Juan V en cuestiones de política exterior ${ }^{6}$.

De ese modo y a la vez que, en mayo, la petite Reine (como era tratada en la Corte de Versalles), regresaba a España, se emprendían las negociaciones entre las dos cortes, no a través de los canales formales de los respectivos agentes diplomáticos, sino de ministros plenipotenciarios nombrados ad hoc, cada uno de ellos empeñado en imponer la estrategia individual de su señor: por la parte portuguesa, José da Cunha Brochado, experimentado, aunque de edad avanzada, a quién le correspondía la espinosa misión de alcanzar el aislamiento de la propuesta matrimonial con respecto al proyecto de la alianza en que venía envuelta. Tarea dificultada, sin embargo, por la ambición de $\mathrm{D}$. Juan $\mathrm{V}$ de, a su vez, aprovechar la ocasión para ver resueltas viejas rencillas arrastradas desde Utrecht (sumadas a diversas cuestiones de menor calibre). 
En este contexto, habrá que aguardar hasta el 2 de octubre para que, tras intrincadas negociaciones por ambas partes, dificultadas aún más mediante escrupulosos ceremoniales, se procediese, finalmente, en Madrid, al anuncio público de la ratificación de los artículos preliminares de los dos contratos matrimoniales, secundada en Lisboa ocho días después. La ocasión daría pie a los usuales festejos, pero el marco estrictamente oficial de las celebraciones en la Corte castellana contrastó con el regocijo exhibido en Portugal, tanto por la adhesión popular, como por las fiestas organizadas por la Corte y por el embajador español, Capecelatro, entre los días 10 y 13 de ese mes ${ }^{7}$.

Como consecuencia de acordar los enlaces, los monarcas procederían al nombramiento de los respectivos embajadores extraordinarios, destinados a formalizar, en una y otra corte, la petición de mano: el de España, marqués de los Balbases, ya en enero; el portugués, marqués de Abrantes, el 2 de febrero de 1726. A pesar de ello, la partida para las respectivas misiones se suspendería hasta finales del año siguiente, $1727^{\circ} \mathrm{y}$, durante el largo periodo que media, la Corte portuguesa no esconde el nerviosismo que el compás de espera le provoca, presionando cuanto puede en el sentido de la formalización de los esponsales (sin dejar, no obstante, por su parte, de dificultar la gestión diplomática, al empeñarse en eludir cualquier compromiso político-militar, e insistir, sin embargo, en la resolución de las cuestiones pendientes).

Por lo que respecta a Madrid, la Corte de Felipe $\mathrm{V}$ pasaba entonces por uno de los periodos negros que ensombrecerían con frecuencia su largo reinado. En efecto, a la crisis política que conduciría a la destitución del ministro Riperdà, en mayo del 26, la inminencia de la guerra con Francia, en julio, que llevaría, asimismo, a la caída en desgracia del valido de la Reina, marqués de Grimaldo, el inicio de la tensión con Inglaterra, frente a Gibraltar, en julio del 27 , que no haría más que agravarse en los seis meses siguientes — todo mezclado con las complejas maniobras de Isabel de Farnesio con respecto a Austria, con vistas a casar a sus hijos Carlos y Felipe y dotarlos de estados italianos, y con Francia, todavía a raíz del caso de Mariannina-, se sumaba la salud del propio Rey, Feli- pe $V$, cuya inestabilidad psíquica alcanzaría un punto crítico, abandonando todo a la gestión turbulenta de la Reina?.

No obstante, ambas cortes consintieron finalmente en separar de la estricta cuestión de los enlaces los aspectos políticos con los que, en un principio, pretendían rodearlos; y en La Granja, el 14 de septiembre, tiene lugar la firma de las capitulaciones matrimoniales de Mariana Victoria y Don José, a las que seguirían, el 1 de octubre, en Lisboa, las de Bárbara y Fernando, en función de las cuales se harían, por fin, las entradas públicas de los embajadores: la de Abrantes, el día de Navidad, la de Balbases, el 6 de enero, alardeando en ambas con la mayor pompa (con mayor implicación pública y popular, como siempre, en la Corte portuguesa), en una emulación de fausto dirigida a preservar la mutua dignidad de las dos monarquías. Y en ese momento queda establecido que las dos cortes se comprometerán a conducir a las prometidas, simultáneamente, a la frontera común, donde se realizarían las entregas ${ }^{10}$ : el desagravio de la afronta realizada a Mariannina pasaba por la reproducción, con igual dignidad, de la escena de la Isla de los Faisanes, donde había sido intercambiada camino de Francia, y, en ese sentido, se había comunicado ya al corregidor de Badajoz, el 19 de septiembre, la decisión regia de realizar ahí la doble boda hispanoportuguesa"1

En consecuencia, Isabel de Farnesio encarga vestidos a París, así como las preceptivas joyas que ofrecer a la nueva Princesa de Asturias, de igual manera que comienzan los trámites para la constitución de su casa ${ }^{12}$; por su parte, también la Corte lusa se abastece en la capital francesa de todo tipo de aderezos destinados a los esponsales (en un primer momento artículos de viaje, medios de transporte, sillas, mantas de montar, etc.), además, naturalmente, del ajuar de la propia Bárbara, creado según la "maior grandeza que se pode imaginar"13. Sin embargo, el secretario de Estado, Diogo de Mendonça Corte-Real, recomienda al agente portugués Francisco Mendes de Góis, el 19 de octubre, que los sucesivos encargos se suministren a base de artículos "ja feitos (porque a brevidade do tempo não dá lugar a que se faça)"14, el mejor indicador de que los matrimonios por fin se precipitaban. 
Efectivamente, con la entrada pública de Balbases, el 6 de enero del 28, para formalizar la petición de la infanta portuguesa, todo parecía indicar, por fin, el comienzo de la cuenta atrás para el doble enlace. El día 10 posterior se otorgan, en ambiente de gala y regocijo en la Corte y delirio popular, las capitulaciones matrimoniales y en ese y en el siguiente (en el cual, en la Basílica Patriarcal, se procede a la boda de la Infanta, actuando el Rey, su padre, en representación del prometido ausente), se iluminaría el Terreiro do Paço con la maquinaria pirotécnica creada por Antonio Canevari, arquitecto romano recién llegado a la Corte lusa, donde hacía la primera demostración de su talento: la primera noche representó el Templo de Diana -enorme y clásico edículo, escoltado por columnas y dominado por la fama, enmarcando la figura de la diosa y asentado sobre un peñasco- y la segunda la cueva del Monte Latmo, con las tres Gracias: esta de factura esencialmente naturalista, en forma de una caverna rocosa en la que se refugiaban las ninfas, con Diana en la parte superior, recostada en una nube y contemplando al pastor Endimión ${ }^{15}$. Y los festejos se prolongarían hasta el día 13, con el panegírico de turno, por medio de la Academia Real de la Historia ${ }^{16}$.

No obstante, se agrava repentina y dramáticamente el estado de salud de Felipe V: en ese mes de enero no solo la demencia del monarca alcanzaría un punto que se consideraba irreversible, sino que llegaría a temerse por su vida, con las consecuencias inherentes, tanto desde el punto de vista de una programación digna de las ceremonias matrimoniales, como, más en concreto, por lo que afectaba al propio poder de Isabel de Farnesio, obligada a admitir a su hijastro Fernando en el consejo de Estado y viéndose ya, con sus hijos, abocada a un destino oscuro (el intento de abdicación que el monarca, una vez más, consigue llevar a cabo, no hace más que confirmar sus recelos ${ }^{17}$ ). El hecho de que Fernando sufriese viruela en mayo resolvía, por el momento, el problema político ${ }^{18}$ (incluso podría resolverlo de manera definitiva...), pero, sobre todo, introducía una nueva perturbación en cuanto a los enlaces, que, todo parecía indicar, no lograrían adelantarse a corto plazo, habiéndose ordenado, de hecho, el regre- so del embajador Balbases, una vez cumplida la específica misión para la que había sido investido ${ }^{19}$.

A pesar de ello, a finales de mayo recibían las autoridades de Badajoz órdenes -infaustas para el estado de las finanzas locales- de proceder al corte de 1.500 troncos para la construcción de los estrados donde se colocaría la comitiva española sobre el río Caya, en la ocasión del intercambio de las princesas ${ }^{20}$. Pero no habría avances efectivos en esta materia en el período inmediato, salvo que, por el lado portugués, había emprendido Don Juan $V$, ya el mes de febrero, la construcción de un palacio en Vendas Novas, destinado a alojar las comitivas reales en la ida y la vuelta de la frontera: obra encargada (et pour cause) a un ingeniero militar, José da Silva Pais, que en América culminaría, posteriormente, una brillante hoja de servicios, y que alcanza a edificarla -así como otras comodidades que se distribuirían a lo largo del camino- en el lapso inverosímil de diez meses ${ }^{21}$. Mientras tanto, todavía en marzo y puede que como medida de presión política (teniendo en cuenta los vínculos familiares que, a pesar del episodio de Mariannina, unían a los Borbones de Francia y España), los Reyes de Portugal comunican oficialmente a los soberanos franceses (Luis XV se había casado, entre tanto, con María Leszczynska) el doble enlace de sus hijos $^{22}$.

Por aquel entonces, súbitamente, a finales del verano, los Reyes de España dan a conocer su propósito de acompañar a la infanta hasta a la frontera: y así lo comunican a Badajoz, el 20 de septiembre ${ }^{23}$. La decisión, insólita y que obligaría a los soberanos portugueses a corresponder igualmente ${ }^{24}-\mathrm{y}$ que estaría en el origen del extraordinario espectáculo de emulación de pompa en que se convertiría el intercambio de las princesas - constituía, según todo indica, una maniobra de Isabel, destinada a alejar a Felipe de Madrid y a protegerse de sus intentos continuos de abdicación, a la vez que del avispero de rumores que, en ese marco aparente de fin de reinado, le minaban el ejercicio del poder. No dejaba, no obstante, de introducir un factor nuevo de complicación, por la incapacidad manifiesta del monarca español, debilitado y completamente demente, para emprender semejante expedición. 
Sin embargo, como de milagro, la noticia llegada a Madrid, en noviembre, de que Luis XV (todavía sin heredero) había contraído la temible viruela, produciría un súbito y aparentemente completo restablecimiento en Felipe, repartido ahora en frenética actividad, con idea de reclamar la respectiva corona: situación que Isabel de Farnesio rápidamente aprovecharía para anunciar, el 17 de diciembre, la partida de la Corte hacia la frontera portuguesa el 7 de enero del nuevo año de $1729^{25}$. Cuando, justamente, se cumplían cuatro años del infausto episodio de la Isla de los Faisanes...

Conocida la noticia en Lisboa, inopinadamente, mediante comunicación oficiosa del embajador Capecelatro, el 19 de diciembre (el 20 llegaría la carta oficial y el 22 la del embajador portugués, el marqués de Abrantes) ${ }^{26}$, se inician, en ambas capitales, en frenesí, los preparativos de la jornada, coordinados en la parte portuguesa, con mano dura, por el duque de Cadaval y el caballerizo mayor Don Jaime Álvares Pereira de Melo, con el apoyo de la logística militar ${ }^{27}$. Por parte española, donde la Corte se mantiene mayoritariamente ajena a la representación ideada por la soberana —que apostará sobre todo por el aparato militar-, una auténtica multitud se lanzará a la ribera del Caya; del lado portugués serán bastantes menos (cerca de 2.000, a fe de las fuentes ${ }^{28}$ ) y el componente bélico será esencialmente ornamental, pero en contrapartida el plantel palaciego figurará en pleno y se hará apuesta, esencialmente, en su presentación.

Sea como fuere, era extraordinaria la expectativa en los dos círculos cortesanos implicados y un espectáculo completamente sin precedentes:

Segurovos -escribía desde Madrid el marqués de Abrantes al conde de Tarouca, también diplomático, el 27 de ese mesque com razam estão todos em expectação de ver da nossa p. ${ }^{\text {te }}$ o mais opulento, e lustrozo espectáculo, que jamais deu Portugal de sy; e desta, posto que a ostentação, quanto ao luxo, não seja tanta, não ha duvida que vay hua numeroza corte, porque sem haver grande, que se rezolva a accompanhar o seu Soberano, salvo o Conde de las Torres, os officiaes da Caza Real, os officios, e os que d'elles dependem, se estima que serão o melhor de dezasseis mil pessoas: vos acabais de ver hua jornada Cesarea, mas cuydo que ella não importava tanto, como estas duas Regias ${ }^{29}$.

Preocupada, esencialmente, por llegar rápidamente a Badajoz, donde entraría el 16 de enero, Isabel de Farnesio estructura la jornada en diez etapas, por completo desprovistas de ceremoniales locales. No así la Corte portuguesa, cuyo recorrido intentaría conciliar el objetivo central de llegar a Elvas con la dignidad inherente a la exhibición real. Con ese objetivo, se organizarían dos cortejos sucesivos (el masculino: del Rey, el Príncipe del Brasil e Infantes, que arrancaría de Lisboa el 8 de enero; y el femenino: de la Reina, la Princesa de Asturias y el infantito Don Pedro, que partiría el 9), en ambos casos observándose idéntico ritual, a pesar de los rigores del invierno y del empeoramiento continuo de las condiciones meteorológicas, que solo mejorarían de cara al final ${ }^{30}$ : partida, en bergantines, del Palacio de la Ribera; desembarque y oraciones en el Monasterio de Madre de Deus; travesía hacia Aldeia Galega y pernocta; continuación hacia Vendas Novas, durmiendo en el palacio nuevo; continuación hacia Évora (y pernocta), con recepción previa en Montemor-oNovo; después Vila Viçosa (haciendo noche) y, finalmente, Elvas, donde Don Juan V Ilegaría, igualmente, el 16, dos horas antes de que, en la plaza fronteriza, las salvas militares anunciaran la entrada de su homólogo español.

A pesar de ello, las entregas no se harían sin percances. De hecho, ciertamente bajo los auspicios de los deseos de Isabel de Farnesio de concluir la ceremonia cuanto antes, Felipe $\mathrm{V}$ comunica al soberano portugués su deseo de proceder al intercambio al día siguiente, el 17. No obstante, ya fuera por entender que los Reyes de España desearían poder concederse algún descanso antes de la función, ya fuera porque la buena orden del aparato que ambicionaba poder ostentar (esencialmente curial y, además, más complejo que el militar español $y$, por otro lado, eficazmente conseguido, si damos por bueno el testimonio del abad Montgon, que escribía que "la pompe avec laquelle il 
vint au pavillon, surpasse tout ce qu'on peut dire"31-) exigiría, aún, algún ensayo previo, a Don Juan $\mathrm{V}$ lo toma de sorpresa, viéndose forzado a ordenar una marcha precipitada hacia el Caya que, sin embargo, ya no consigue alcanzar a la comitiva castellana, que había emprendido el retorno a Badajoz. Después de las justificaciones y debidas conferencias preliminares sobre el meticuloso ceremonial que debería observarse, por parte de los secretarios de Estado de las dos potencias, se aplaza, finalmente, hasta el día 19 el anhelado intercambio en el suntuoso pabellón construido ex profeso y donde, de hecho, por efecto del meticuloso protocolo concebido, "En un mot, l'égalité des deux parts avoit été scrupuleusement observe", como, de nuevo, resumiría Montgon ${ }^{32}$.

Las dos familias reales y sus respectivas comitivas tendrían aún que volver a encontrarse, dos veces más (el 23 y el 26), en ambiente, ahora, de relativa informalidad (particularmente), antes de despedirse definitivamente: la portuguesa para el regreso a Lisboa y la entrada solemne de los nuevos Príncipes del Brasil; la castellana rumbo a Sevilla y al famoso lustro en el cual, durante cuatro años, Isabel de Farnesio lograría aislar a Felipe $V$ de los mentideros de Madrid $^{33}$. Atrás quedaba, no obstante, y directamente entroncado con este episodio desde todos los aspectos excepcional, principalmente del lado portugués (fruto de la dignidad que Don Juan $\vee$ se esforzó, en todo momento, por imprimir al acto, a pesar de la dificultad de encajarlo con el ritmo peculiar del proceso decisorio por parte de la Monarquía castellana, al cual, forzosamente, tendría que ajustarse), todo un conjunto de empresas relevantes desde el punto de vista de la Historia del Arte (a veces, incluso, en el estricto ámbito de la cripto-Historia del Arte), que absorberían, ciertamente, una parte sustancial de los siete millones de cruzados que, de acuerdo con las fuentes, costaría al monarca la suntuosísima excursión ${ }^{34}$.

$Y$ en ellos destacan, especialmente, la enorme mansión de Vendas Novas y el pabellón del Caya (con respecto al cual, justamente, emergen hoy nuevos elementos). Sin embargo, su correcta apreciación y la contextualización a la que, naturalmente, obligan, desde el punto de vista del conocimiento ya consolidado acerca de las estrategias del mecenazgo artístico del monarca luso imponen, necesariamente, la consideración de las estrictas contingencias del contexto histórico - perturbado y, asimismo, realmente extraordinario- en que habrían de generarse.

En realidad, y más allá de las consecuencias directas, nunca registradas sistemáticamente, que el paso del dadivoso monarca generaría en lo referente al patrimonio local de los principales núcleos urbanos que salpicaban el itinerario de la función, flota una espesa nebulosa, sobre todo, sobre el barroquismo regional de los festejos municipales, absolutamente ausente en la parte española, a causa del imprevisto anuncio de la partida y de la estrategia real de llegar cuanto antes a Badajoz, y que aquí incluso adquirían una tímida expresión. De hecho, no es hasta llegar a Sevilla, hacia donde se traslada a continuación la Corte, que sorprende su total exhibición, en un marco genérico en el cual no deja de asombrar la capacidad de improvisación demostrada ${ }^{35}$

Por la parte lusa, sin embargo, evocan las fuentes la ornamentación de Montemor-oNovo (cuatro arcos triunfales, realizados por los artistas locales Francisco Salas, Francisco de Cardenas, Sebastião Mendes Oliveira y Martinho Francisco), de la cual no quedaría ilustración, sucediendo otro tanto con Évora (un arco, en la calle de Selaria, construido por orfebres en oro y plata; otro en la calle de Anca, de los mercaderes; otro más en la calle de Lagoa, de los oficiales de las banderas de San José y San Jorge, abalizando el recorrido hasta la (atedral), con Vila Viçosa (dos arcos triunfales y preparación de las puertas y fuentes del recinto urbano) y, por último, con Elvas (arcos en la calle de Olivença, en la calle de Carreira y en la puerta de la Plaza $)^{36}$, sorprendiendo en la documentación los efectos del control real, referido a la normalización y decoro, tanto del escenario, como de los ceremoniales, con respecto a posibles ingerencias de la tradición regional. De esta forma, en Évora, el cabildo, movilizando sus recursos, se aprovisiona en Lisboa para la ornamentación de la Catedral, al tiempo que, en Elvas, el ayuntamiento recomienda expresamente que "não houvesse danças ridículas como em outros tempos haviam", imponiendo que, en el trayecto 
conducente a la catedral, la ornamentación de puertas y ventanas privadas se haga únicamente recurriendo a sedas ${ }^{37}$.

En realidad, a causa de la intempestiva decisión de partir hacia la frontera el 6 de enero tomada por la Corte española y no transmitida, tanto a Badajoz como a Portugal, hasta escasos días antes de la Navidad, la comunicación formal, por su parte, a la diversas ciudades por las que habría de pasar la comitiva nacional no se realizaría antes del 2 de enero ${ }^{38}$ : así que puede adivinarse bien la premura sufrida. Pero, siendo Caya, por tradición, el enclave de paso de las princesas casaderas entre los dos países (y, consabido, por lo tanto, el trayecto a seguir por las dos prometidas reales, independientemente de las proporciones que el intercambio adquiriría con el tiempo) y ante la aparente inminencia de la celebración de las bodas tras la firma de las capitulaciones matrimoniales en el otoño de 1727, Elvas (así como las demás, se supone) había sido notificada en mayo de 1728 por el gobernador de armas de la provincia de Alentejo acerca de la orden real de hacer ornamentar la urbe y las

mais terras por onde houvessem de passar as Sereníssimas Senhoras Princesas deste reino de Portugal e Castela ${ }^{39}$.

Con el ciclo de las entregas, de hecho, se relacionarán, igualmente, las obras puestas en marcha por Don Juan $V$ en la imponente mansión de sus padres -el Palacio Ducal de Vila Viçosa-, donde había estado en 1716 y adonde difícilmente habría vuelto, seguro, si no fuese por la obstinación de la soberana castellana por llevar la Corte a Badajoz y por superar en exhibición de fausto el episodio de la Isla de los Faisanes: concretamente, la construcción de la nueva cocina y respectivos anexos (cuya contratación se encuentra documentada en 1728), aunque, especialmente, el programa decorativo de la Sala de los Tudescos, con la serie ducal pintada por Duprà y cuya cronología se fijaría, en la tradición historiográfica, en torno a $1725^{40}$ : datación (media) verosímil, a partir del análisis iconográfico de los retratados (del propio Rey, de Bárbara y de Don José). O sea, en concomitancia con las propuestas matrimoniales.
Ocupaba un espacio central, además, el denominado Palacio de Vendas Novas, edificado con el objetivo esencial de dar refugio a las reales comitivas en el punto intermedio del trayecto entre Lisboa y Évora. Empezado en febrero de 1728 y concluido por todo o mez de Dezembro

- como diría el cronista só não pôde caber no tempo, acabar de pôr a ultima mão em alguma pequena porção, que ficou por repartir, em desenho (El-Rey de Portugal añade à su grandeza la de hacer milagros, exclamaría Montgon al verlo)—,

si confiamos en las fuentes, en él habrían trabajado, bajo el mando disciplinario de Silva Pais, cerca de 2.000 hombres, alcanzando la obra un importe de un millón de cruzados, entre estructura y ornamentación ${ }^{41}$. En esencia se trata de una vasta mole desprovista de adornos, de dos pisos y con carácter funcional (a pesar de que las fuentes mencionan también, junto a Silva Pais, el nombre del Arquitecto Custódio Vieira); con alas de planta baja destinadas a albergar los talleres, de los cuales el del extremo derecho remata en una capilla. Este palacio permanece globalmente desconocido desde el punto de vista de la investigación, víctima de la negligencia y del inapropiado uso militar al que sería destinado desde el siglo XIX $\mathrm{X}^{42}$.

A pesar de esto, sobrevive en él aún un conjunto destacable $-y$ extremadamente interesante- de techos pintados sobre tela (por obvias cuestiones de rapidez; los de la planta baja, de hecho, simplemente esbozados en lo esencial), en relación a los cuales se establecería incluso un parentesco formal con obras paralelas del Palacio de Belém y se atribuirían al nombre de Vitorino Manuel da Serra, mencionado por los panegiristas como el introductor en Portugal del "primoroso ornato francês"43. Perdura también el espléndido retablo de la capilla y, en esencia, la distribución interna: con el atrio llamado de los Tudescos y la división canónica, entre las alas del Rey y de la Reina, correspondientes, a nivel de la planta baja, con los aposentos de la Princesa de Asturias y del Príncipe del Brasil ${ }^{44}$. 
En todo esto, sin embargo, ocupa el lugar central, como no podría ser de otro modo, la denominada casa de las entregas: el pabellón que, sobre el río Caya, debería albergar el punto culminante de la función, sirviendo de escenario al enfrentamiento final entre las dos Cortes, en emulación de magnificencia. De él se conoce, hace mucho, un proyecto de planta, alzado y corte, conservado en el Archivo Histórico de Madrid, además, naturalmente, de las descripciones redactadas por los cronistas. No obstante, la aparición de dos dibujos nuevos pertenecientes al mismo fondo documental y referentes a la casa de las entregas uno y a los trabajos de ingeniería a los que obligó la determinación alimentada por las dos Coronas -y que Montgon constataría - de respetar escrupulosamente, en el acto ceremonial, l'égalité des deux parts el otro impone que nos detengamos más sobre el asunto, empezando por el último tema, que posee realmente un mayor interés del que se podría imaginar a primera vista.

En efecto, el lugar destinado al intercambio había sufrido sustanciales alteraciones desde que, en 1543, se había entregado allí, por última vez, a una prometida real: concretamente, a Doña María de Portugal, hija de Don Juan III y Doña Catalina de Austria, destinada a contraer matrimonio con el futuro Felipe II de España ${ }^{45}$. En realidad, aunque en la práctica se tratase de un modesto riachuelo solía sufrir inundaciones importantes que, con el tiempo, le habían hecho abandonar su lecho primitivo y pasar a discurrir por tierras españolas en las inmediaciones de la carretera Elvas/Badajoz: Del lado español se construyó un puente de madera, mientras que sobre la antigua viga madre permanecía, abandonado y cubierto de arena y tierra, el puente de piedra original ${ }^{46}$. En este contexto $y$, probablemente, tras la firma, en el otoño de 1727, de las capitulaciones matrimoniales y de la decisión en ellas presente de proceder a la conducción simultánea de las dos prometidas a la frontera, recreando, en beneficio de Mariannina, la escenografía de la Isla de los Faisanes ${ }^{47}$, Feliciano de Bracamonte, comandante general de la provincia de Badajoz, recibiría el encargo de realizar un estudio de las condiciones del puente y del río, así como de las obras necesarias.
En ese sentido y ante la necesidad de hacer respetar, en la insólita y regia función, l'égalité des deux parts, se empeñaría en aprovechar el puente antiguo, situado en la frontera entre los dos reinos. Lo cual exigía construir un dique, para obligar al curso de agua a desplazarse a su antiguo lecho fronterizo, limpiando y reparando la vieja viga madre, poco profunda e invadida por la vegetación, y, naturalmente, consolidar y reparar el antiguo puente de piedra, que debería servir de base para una edificación de madera, aunque digna del evento que le correspondía albergar. Bracamonte enviaría a su monarca el proyecto correspondiente (que se conserva en el archivo de Madrid $^{48}$ ) y el cálculo de los costes de la obra, así como su respectiva duración: dos meses de trabajo. Los cuales resultarían aprobados y, en función de ellos, tendría lugar, en la raya, una entrevista con un enviado de la Corte portuguesa. Sin embargo, esta, siempre deseosa de imprimir la mayor celeridad al complejo e interminable proceso de intercambio de las princesas, responde que era menester una obra más breve, capaz de concluirse en veinte días, ofreciendo, con ese objetivo, la sugerencia de un puente de barcas sobre el río, para el paso de las dos comitivas, llevándose a cabo las entregas en pabellón erguido sobre la orilla.

En vano: ante la posibilidad de que el acto pudiese llegar a celebrarse en un emplazamiento indigno de tal acontecimiento, desde España contestan que están dispuestos a esperar lo que fuere necesario. En este contexto, herido en su real orgullo, D. Juan $V$ ofrece un nuevo proyecto, más ambicioso y opulento aun que el español. Al cual contestan Felipe e Isabel que no tenían nada que objetar, pareciéndoles todo poco con respecto a la dignidad de sus hijos ${ }^{49}$. La obra arranca así, destinando a ella, Portugal y España, 500 hombres cada país; los trabajos de limpieza del río, construcción del dique y reparación del puente empiezan el 10 de mayo de 1728 y se prolongan hasta finales del mes de septiembre. Al mismo tiempo, se prepararían los materiales para lacasa, la cual, sin embargo, se decide no montar, ante la llegada del invierno, hasta conocer con certeza la fecha del intercambio de las princesas ${ }^{50}$.

Por lo que respecta al pabellón propiamente dicho, son conocidas, hace mucho, las descrip- 
ciones aportadas por las fuentes, en particular la más minuciosa, que registra Fray José da Natividade, el cronista portugués del evento. Sabemos, de esta forma, que este, a fin de garantizar meticulosamente la obsesiva igualdad de las partes, estaba constituido por

três Casas: as duas dellas collateraes, para cada hum dos Monarcas, nos seus domínios; e a do meio, arquitectada também com tal disposição que cada hum dos Monarcas tinha assento nos seus domínios, para a cerimónia das Reaes entregas.

Natividade también presta especial atención al esplendor de la decoración interna, mencionando solo, con respecto a la estructura del edificio efímero, que contaba con noventa y ocho palmos de superficie y se adornaba

a fachada exterior da Casa de Castella com as Armas Reaes daquella Coroa, e triunfavao semelhantemente na de Portugal, entre duas figuras allegoricas, as suas sagradas, e tantas vezes Triunfantes Quinas ${ }^{51}$.

Sin embargo, un poema manuscrito coetáneo, redactado, muy probablemente, por un testigo presencial, facilita información más detallada.

Menciona, en efecto, los

quatro cunhaes em que formavao / desta obra seus cantos magestozos / quatro figuras de fama celebravam / estes júbilos régios gloriosos,

así como que

As armas portuguezas que adornavam / em seu pórtico o ponto mais subido /duas regias figuras sustentavam /Atlantes deste ceo engrandecido,

o también que

Dois leões da Arcania eram quem davam / soberba a este pórtico luzido / que no mais na igualdade de modello / com o outro corria paralello / tendo mais cada pórtico a seu lado / duas janelas de igual grandeza / das que estava o palácio rodeado / todas feitas de igual custo a riqueza / o seu numero dellas bem contado / vinte e duas fazia em redondeza / (...) Nove janellas tinha em cada lado / que ocupavam de lado toda a parte.

$Y$, con respecto al esplendor de esa arquitectura aparente, no olvida constatar que

O pórtico que tinha nesta entrada / era todo de talha mais subida / donde o ouro fazia mais sobradas / a soberana maquina erigida, que las ventanas eran em caixilho vermelho ajiletado / de ouro puro a vidraça transparente / com simalhas azuis de pedra fina, etc ${ }^{52}$.

Por su parte, del lado castellano, donde las fuentes serían más lacónicas, una minuciosa relación de las festividades organizada por el Ayuntamiento de Badajoz describe en estos términos la estructura del pabellón:

a espenssas del Rey Ntro Señor y de S. M. lusitana, se favricó una sumptuosa cassa de Madera que constava de três galerias tan capaces que ocupavan quattro de los primitibos arcos del médio de suerte que el segundo salon comprehendia de médio a me[dio]la rivera de forma que la una sala y la mitad del zentro dividia el término de Castilla y la otra y media restante el de Portugal ocupando su território conque unida, cada mitad, contraria la de la parte de Castilla, de quatro valcones y médio, y otros tantos la de Portugal; conque el todo del Palazio por cada uno de los costados, tenia nuebe balcones con três puertas y ventanas de cristales finos, y toda arquitectura pintada de fingidas piedras [...]Piedra azul, Piedra encarnada y Piedra verde... ${ }^{53}$.

De este pabellón la historiografía conoce hace tiempo un bello dibujo, compuesto por planta, alzado y corte longitudinal, realizado 
por la parte española, por medio de los ingenieros Felipe Crame y Juan Frentchqueson, en una arquitectura digna y sobria que sigue los cánones clásicos de la arquitectura militar ${ }^{54}$ (y acerca del cual fue ya establecida su condición de "obra concebida con un fin eminentemente práctico" ${ }^{155}$ ). No obstante, suscita obvios problemas de correspondencia con las descripciones - concordantes, en realidad - registradas por los memorialistas, principalmente por lo que respecta al número de ventanas que los pabellones poseían: seis por lado, que estos afirman ser nueve; junto con las dos que, en cada parte superior, flanqueaban las entradas $-\mathrm{y}$ serían cuatro en este-, sumaban un total de veintidós. $E$, incluso, por lo que respecta a aspectos decorativos, como las pilastras de las esquinas, donde, como dice el poema, "quatro figuras de fama celebravam / estes júbilos régios gloriosos": el dibujo conocido exhibe, en ese lugar, cuatro obeliscos rematados por esferas. De igual modo, nada en ese proyecto sugiere el esplendor de tallas recubiertas de dorado y fingidas piedras multicolores de las que se componía el pabellón según sus cronistas, ilustrando un artificio de puro efecto de cantería, al servicio de un diseño ya de hecho proto-neoclásico. Al mismo tiempo, al ser de pura autoría castellana, obra de los ingenieros militares Felipe Crame y Juan Frentchqueson, y carecer en realidad de contacto formal con la estética de Ludovice y con lo que se conoce de la de Canevari, quienes colaborarían por la parte portuguesa en la función, con plenos indicios de que las festividades del intercambio de las princesas fueron la razón de fondo del desplazamiento de este último a Portugal ${ }^{56}$, no podría dejar la historiografía lusa de entenderlo como de problemática interpretación, probablemente ilustrativo de la fase intermedia del programa ${ }^{57}$.

Sin embargo, ahora se sabe que, a consecuencia del encargo asignado al comandante general de la provincia de Badajoz, Feliciano de Bracamonte de realizar un estudio de las condiciones ofrecidas por el río Caya y su(s) puente(s), muy probablemente tras la firma, en otoño de 1727, de las capitulaciones matrimoniales y de la consiguiente decisión de proceder a la conducción simultánea de las dos prometidas a la frontera, este elaboraría, en consecuen- cia, un proyecto de las obras necesarias, que incluían devolver el río a su antiguo cauce mediante la construcción de un dique y aprovechando esta circunstancia para asentar la casa de las entregas en el puente antiguo, a cuya reparación se procedería. Y se sabe también que el proyecto, aprobado por la Corte de Madrid, despertaría la oposición de la parte portuguesa, empeñada en imprimir al intercambio la mayor celeridad, motivo por el que aporta otra idea, susceptible de concluirse en veinte días. Pero que esta última chocaría con la obsesión escenográfica de Isabel de Farnesio, empeñada en enmendar el agravio de la pequeña Mariannina y en impedir que su nueva boda tuviera menos brillo que aquella otra que había comenzado en la espléndida jornada de la Isla de los Faisanes. Por este motivo, herido en su dignidad de monarca (y padre), Don Juan $\mathrm{V}$ propone un nuevo proyecto, más ambicioso y opulento ahora, y que obtiene, de hecho, el beneplácito de sus homólogos españoles. En dicho proyecto, obviamente, los arquitectos de la Corte portuguesa tendrían el papel principal y su ejecución ocuparía los meses de mayo a septiembre de 1728.

El archivo de Madrid conserva, en el mismo fondo, otro dibujo referente a la función del Caya: un diseño parcialmente anotado en portugués ("ponte";"plano da casa"), aunque con presencia, asimismo, de leyendas en castellano (añadidas), que afirman perentoriamente que se trata del "Plano Perfil y Elevaziones que se ha dado por Portugal de la Casa que se ha de hazer sobre el Puente del Rio Caya"158. Pero, sobre todo, se trata de un proyecto coincidente en su integridad con las descripciones registradas por los memorialistas, fundamentalmente por lo que respecta al número de huecos (veintidós ventanas, además de las puertas principales) y a la presencia de los ángeles-fama en las pilastras de las esquinas, siendo, obviamente, común (puesto que era obligatorio) el aparato heráldico de los portales de acceso. Así pues, todo indica, que este es el proyecto realizado de hecho y en el cual, de esa manera, correspondería por fin a la Corte portuguesa (y a sus artistas) el papel principal, a consecuencia de la peculiar gestión político-diplomática de este proceso — peculiar en sí mismo-y de la cual 
no podrían disociarse objetivamente, en efecto, los aspectos estrictamente artísticos, teniendo en cuenta la efectiva inviabilidad práctica de proceder a un proyecto conjunto del componente escenográfico de las entregas. En cualquier otro lugar serviría, en realidad, para afianzar la distribución de esfuerzos.

Este sencillo - y un tanto rudo- esbozo de un proyecto con toda probabilidad concluido (cuyo trazado, como de costumbre, se habrá consumido en la efervescencia del astillero), ilustra de hecho, mediante planta, alzados frontal y lateral y corte transversal de la sala media, un recinto de mayor monumentalidad y extensión, ampliado en cerca de un tercio con respecto al proyecto original español. Está cubierto por un tejado único a cuatro aguas - por oposición a los tres sucesivos del plano primitivoy posee una cierta cadencia, aportada por los alzados laterales de pilastras jónicas adornadas con guirnaldas, todo ello coronado con platabanda balaustrada, ornamentada con urnas y flanqueada, en las pilastras de las esquinas, con ángeles-fama. Este tema solo se ve interrumpido por el frontón que, en cada pináculo, remata el portal de acceso, dominado por el aparato heráldico de las dos Coronas, imprescindible para la correcta observancia de la obsesiva égalité des deux parts que alimentaría, en toda su extensión, el programa ceremonial del intercambio de las princesas. El tema, detallado solo y de forma sumaria en una muestra en el marco de una ventana borrominiana, las pilastras que la flanquean y la balaustrada de remate y respectivas urnas, resulta, no obstante, suficiente para alejar del programa la mano de Ludovice, ya fuera por la relativa sequedad de su proyecto, seguramente compensada por los esplendores de la ejecución del trampantojo, tanto exteriormente como en la decoración interna de la sala y media que le competía, o por el carácter general de la ejecución del esbozo, inconciliable con su consabida sensibilidad con respecto al valor del ornato y defensa intransigente de la majestad de la composición.

A la inversa, ese academicismo árido distingue, justamente, lo que se puede adivinar sobre el particular estilo de Canevari. Otro tanto se puede decir de su gusto por determinados recursos compositivos, como es el caso del tema de las pilastras con guirnaldas de orden jónico, con repercusión a modo de marca de agua en la fachada, todavía románica, de la Iglesia de los Estigmas, sus primeros trabajos portugueses, como la torre de la Universidad de Coimbra ${ }^{59} \mathrm{O}$ las arquitecturas efímeras de los fuegos artificiales que, en Lisboa, marcarían, a comienzos de ese año (por fin), la firma de las capitulaciones matrimoniales. $Y$ donde, de igual modo, se divisa la Fama ${ }^{60}$ como imagen. $Y$ tal vez sea ese especial protagonismo en la programación artística de las suntuosas entregas — que, necesariamente, abre otros frentes de investigación- la razón de fondo del protagonismo que, a su vez, aparentemente tiene, como ya ha sido señala$\mathrm{do}^{61}$, en el propio contexto ceremonial. En el registro de arquitectos consta, efectivamente, con su ayudante (Nicolao Moribello, Genoves a quien, por cierto, alberga en su casa, en Rua Larga de $\mathrm{S}$. Roque, en la Pascua de ese mismo año $\left.{ }^{62}\right)$, antes que Ludovice y su ayudante ${ }^{63}$. Puede que a dicha situación no le hayan sido ajenas, en el obvio enfrentamiento con el alemán, las vicisitudes que rodearon, una vez concluido el capítulo de las entregas, la carrera portuguesa del romano...

No obstante, antes de Canevari destaca otro nombre en la estricta mesura protocolar de los carruajes, a saber: Francisco Pereira da Fonseca, al que Natividade se refiere como el "sargentomor e engenheiro da praça de Setúbal, que modelou a ponte sobre o rio Caia" ${ }^{64}$, y cuyo puesto, en la estructura corporativa oficial (de sargento mayor e ingeniero) le justificaría un obvio precedente. Resultan sintomáticamente silenciosas las fuentes castellanas sobre esta materia, de la misma forma que los cinco arcos de medio punto sobre los que se asienta el proyecto conocido no armonizan con lo que puede observarse todavía en la actualidad. De hecho, la observación demuestra que el apoyo eran tres arcos abatidos, con sus tajamares y la presencia de tablero cóncavo con respecto a los patines de acceso, claramente enmarcado, en realidad, en el carácter de la ingeniería militar del monarca portugués e ilustrativo, en lo esencial, de la obra original, aunque en las entregas del lado castellano mostrase, quizás debido a la erosión ribereña, un claro reaprovechamiento de estructuras anteriores. 
Todo se concilia de este modo para demostrar que, en virtud de la aceptación, por parte de la Corona española del proyecto aun más ambicioso que Don Juan $V$ contrapone al original elaborado por ésta, que se ilustra en el dibujo conocido, debido al rechazo de su sugerencia inicial de realizar una obra rápida, susceptible de ejecutarse en veinte días, haya correspondido a Portugal, a este respecto, un particular protagonismo, concentrándose la participación española en el proyecto hidráulico de construcción del dique y desmontaje del lecho nuevo por donde corría el Caya, que Bracamonte había organizado. Y, al asumir la Corte lusa, al mismo tiempo y por medio de Antonio Canevari y de Francisco Pereira da Fonseca, el diseño de la suntuosa casa de las entregas y del puente sobre el que habría de asentarse, el proyecto materializaría la respuesta altiva del monarca portugués a las exigencias de Isabel de Farnesio.
No obstante, probablemente aportaría expresión, justificando, de esa manera, la tranquila adhesión de su colega español, al propiciar a Mariannina un marco todavía más fastuoso que el que había contemplado en la Isla de los Faisanes. Y, por todo ello, desde Madrid el embajador Abrantes podía justamente afirmar

que com razam estão todos em expectação de ver da nossa p. ${ }^{\text {te }}$ o mais opulento, e lustrozo espectáculo, que jamais deu Portugal de sy.

Hoy en día solo se puede reconstruir con fiabilidad basándonos en el conocimiento cabal de las vicisitudes en que se generó. Por ello, el marco histórico se revela siempre fundamental para el conocimiento del proceso artístico, al cual determina de manera objetiva, aun cuando sea menos peculiar que la intrincada madeja político-diplomática en la que hubo de llevarse a cabo el intercambio de las princesas.

\section{NOTAS}

* Traducción: Ángela I. Sola Bravo.

1 Efectivamente y tras extensa controversia historiográfica, en la que, principalmente, se empeñaron, por parte de la primacía portuguesa en la propuesta, Alfonso DANVILA (Fernando VI y Doña Bárbara de Braganza, 1713-1748, Madrid, 1905), RODRíGUEZ VILLA (Revista de Archivos, Bibliotecas y Museos, tomo II, pág. 192) y Antonio de BALLESTEROS $Y$ BERETTA (Historia de España y su influencia en la Historia Universal, 1918-1941, tomo V, pág. 81) y, por la tesis inversa, Caetano BEIRÃO, (Cartas da Rainha $D .{ }^{a}$ Mariana Vitória para a sua família de Espanha, Lisboa, 1936, pág. LXI-LXVI y Eduardo BRAZÃO, Relações externas de Portugal: Reina- do de $D$. João $V$, Lisboa, 1937), sería la materia cabalmente aclarada por María Teresa BARRENECHEA ("María Bárbara de Braganza, Princesa de Asturias", Eidos, $n^{\circ}$ 4, Barranquilla, 1956, pág. 33), dando finalmente la razón a lo que, en su tiempo, habían afirmado los cronistas lusos contemporáneos, D. António Caetano de SOUSA [História Genealógica da Casa Real Portuguesa, Lisboa, 1741, tomo VIII, pág. 151 ( $2^{\mathrm{a}}$ ed., Coimbra, Atlântida Editora, 1951)] y Fray José da NATIVIDADE (Fasto de Hymeneo, Lisboa, 1752, pág. 4-5). La propuesta, efectivamente, tendría como punto de partida una comunicación del secretario de Estado de Felipe $V$ de España, Grimaldi, dirigida al embajador en Lisboa, Capecelatro, con fecha de 12.04.1725. En realidad, desde principios de mes, la propia reina Isabel de de Farnesio comunicaba al Papa, al corriente de la noticia del repudio, su intención de "casar á mi primogénito [metafóricamente: se trataba de su hijastro y heredero, el Príncipe de Asturias]en Portugal, y mi hija con el Príncipe hijo del citado Rey [D. Juan V], en lo que tenderé grandíssimo placer, tanto por estar mal con Francia, como por contar aliados para cualquier medida que pudiera adoptarse contra mi" (A. DANVILA, ob. cit., pág. 43).

2 Cfr. TAXONERA, Luciano de, Isabel de Farnesio. Retrato de una Reina y perfil de una mujer (16921766), Barcelona, Editorial Juventud S. A., 1943, pág. 108-109.

${ }^{3}$ Ob. cit., pág. 96-97.

${ }^{4}$ Sobre este episodio, consúltese, en síntesis, BEIRÃO, C., ob. cit., pág. LIII-LIV y LXVIII-LXXI.

${ }^{5}$ Cfr. DANVILA, A., ob. cit., pág. 45-47, 49-51 y 59; BEIRÃO, C., ob. 
cit., pág. LXXII-LXXVII e LXXXII-XCIV; BARRENECHEA, M. T., ob. cit., pág. 34; NATIVIDADE, F. J. da, ob. cit., pág. 6; SANTARÉM, Vizconde de, Quadro elementar das relações politicas e diplomáticas de Portugal, vol. 2, París, 1842, pág. 189 y 195 y MARTINEZ, Pedro Soares, História Diplomática de Portugal, Lisboa, Editorial Verbo, 1992, pág. 188

${ }^{6}$ Cfr. PIMENTEL, António Filipe, Arquitectura e Poder: o Real Edifício de Mafra, Lisboa, Livros Horizonte, 2002, pág. 29-31.

${ }^{7}$ Cfr. SOUSA, D. A. C. de, ob. cit., tomo 8, pág. 151-152; NATIVIDADE, Fr. J. da, ob. cit., pág. 8-11; DANVILA, A., ob. cit., pág. 53-54; BEIRÃO, C., ob. cit., pág. XCII-XCIV; BARRENECHEA, M. T., ob. cit., pág. 37; TEDIM, José Manuel, "O triunfo da festa barroca. A Troca das Princesas", Arte Efémera em Portugal, Cat., Lisboa, Fundación Calouste Gulbenkian, 2000, pág. 175 y GÓMEZ URDÁÑEZ, José Luís, Fernando VI, Madrid, Arlanza Ediciones, 2001, pág. 29.

${ }^{8}$ Cfr. NATIVIDADE, Fr. J. da, ob. cit., pág. 14 y DANVILA, A., ob. cit., pág. 59-60.

${ }^{9}$ Cfr. BEIRÃO, C., ob. cit., pág. XCIX-CX; DANVILA, A., ob. cit., pág. 56 y GÓMEZ URDÁÑEZ, J. L., ob. cit., pág. 29.

${ }^{10}$ Cfr. SOUSA, D. A. C. de, ob. cit., pág. 191-195 y 214-218; NATIVIDADE, Fr. J. da, ob. cit., pág. 17, 36 y 118; DANVILA, A., pág. 59-61 e 7475; BEIRÃO, C., ob. cit., pág. CIXCXIV; BARRENECHEA, M. T., ob. cit., pág. 37-41; TEDIM, J. M., ob. cit., pág. 175-176; GÓMEZ URDÁÑEZ, José Luís, pág. 29-30 y CASSOTTI, Marsilio, Infantas de Portugal, Rainhas em Espanha, Lisboa, A Esfera dos Livros, 2007, pág. 253.

${ }^{11}$ Cfr. GÓMEZ URDÁÑEZ, J. L., ob. cit., pág. 31.

${ }^{12}$ Cfr. DANVILA, A., pág. 59 y nota (3).

${ }^{13}$ NATIVIDADE, Fr. J. da, ob. cit., pág. 247.

14 Cfr. Boletim da Academia
Nacional de Belas-Artes, tomo I, 1935, pág. 22 y 25.

${ }^{15}$ Cfr. NATIVIDADE, Frei. J. da, ob. cit., pp, 67, 78, 88; TEDIM, J. M., ob. cit., pág. 177 y 192; CORREIA, Ana Paula Rebelo, "Fogos de artifício e artifícios de fogo", Arte Efémera em Portugal, Cat., Lisboa, Fundación Calouste Gulbenkian, 2000, pág. 123128; PIMENTEL, António Filipe, "Ascensão e queda de António Canevari: reflexões sobre um problema historiográfico" (en imprenta).

${ }^{16}$ Cfr. SOUSA, D. A. C. de, ob. cit., pág. 215-218; NATIVIDADE, Fr. J. da, ob. cit., pág. 119-120.

${ }^{17}$ Cfr. DANVILA, A., ob. cit., pág. 74-75; VOLTES, Pedro, La vida y la época de Fernando VI, Barcelona, Ediciones Planeta, 1998, pág. 43-45.

${ }^{18}$ Cfr. VOlTES, PÁG. , ob. cit., pág. 45.

${ }^{19}$ Cfr. DANVILA, A., ob. cit., pág. 75.

${ }^{20}$ Cfr. GÓMEZ URDÁÑEZ, J. L., pág. 31-32.

${ }^{21}$ Cfr. NATIVIDADE, Fr. J. da, ob. cit., pág. 134: VITERBO, Sousa, Dicionário histórico e documental dos arquitectos, engenheiros e construtores portugueses, Lisboa, INCM, 1988, vol. III, pág. 41-42.

${ }^{22}$ Cfr. SANTARÉM, V. de, ob. cit., tomo $V$, pág. 244.

${ }^{23}$ Cfr. GÓMEZ URDÁÑNEZ, J. L., pág. 32.

${ }^{24} \mathrm{Cfr}$. BARRENECHEA, M. T., ob. cit., pág. 43

${ }^{25}$ Cfr. DANVILA, A., pág. 88-89; TAXONERA, L., pág. 169; BEIRÃO; C., ob. cit., pág. CXXII-CXXIV; GÓMEZ URDÁÑEZ, J. L., pág. 30-31; VOLTES, PÁG., pág. 51-52.

${ }^{26}$ Cfr. NATIVIDADE, Fr. J. da, ob. cit., pág. 139.

${ }^{27}$ Cfr. BEIRÃO, C., ob. cit., pág. CXXVI.

${ }^{28}$ Cfr. NATIVIDADE, Fr. J. da, ob. cit., pág. 198-199.

${ }^{29}$ Cfr. BEIRÃO, C., ob. cit., pág. CXXV. Consúltese tb. PÉREZ CAMINERO, Ramón, Bodas reales en Badajoz:
"Bárbara de Braganza - Fernando de Borbón", Reyes de España, 17461758/59. Documentos del Archivo Histórico Provincial de Badajoz, Badajoz, Junta de Extremadura, 2003, pág. 60.

${ }^{30}$ Consúltese, sobre este aspecto (de parte a parte) y el trayecto del viaje: NATIVIDADE, Fr. J. da, ob. cit. (prólogo) y pág. 105, 109-110, 140146, 155, 162, 165, , 169-172, 174 , 180, 189-190, 192-197, 204-215, 217-226; SOUSA, D. A. C. de, ob. cit., tomo VIII, pág. 152-157; DANVILA, A., pág. 92-93; BEIRÃO, C., ob. cit., pág. CXXVI-CXXXII; BARRENECHEA, M. T., ob. cit., pág. 46-48.

${ }^{31}$ Cfr. MONTGON, Charles Alexandre de (Abad de), Mémoires de Monsieur l', Lausanne, 1750, pág. 106 (trad. port. "Do Caia ao Paço da Ribeira", CHAVES, Castelo Branco, Portugal nos séculos XVII e XVIII, quatro testemunhos, Lisboa, Lisoptima, 1989). La opinión es, por otro lado, corroborada por otras fuentes: cfr. DANVILA, A., ob. cit., pág. 96 y PÉREZ CAMINERO, R., ob. cit., pág. 62-63 y 115.

${ }^{32}$ Cfr. ob. cit., pág. 106.

${ }^{33}$ Consúltese: SOUSA, D. A. C. de, ob. cit., tomo VIII, pág. 157-163; NATIVIDADE, Fr. J. da, ob. cit., pág. 227-242, 277-278 e 284-285; DANVILA, A., ob. cit., pág. 93-96; BEIRÃO, C., ob. cit., pág. CXXXIII-CXL; BARRENECHEA, M. T., ob. cit., pág. 49-54; PÉREZ CAMINERO, R., ob. cit., pág. 61.

${ }^{34}$ Cfr. TEIXEIRA, José de Monterroso, "Arte, representação e espectáculo: o programa artístico e os festejos da "troca das princesas" em 1729", Festa Barroca a Azul e Branco, Cat., Lisboa, Fundación Ricardo Espírito Santo Silva, 2002, pág. 55. No obstante, el importe deberá imputarse al conjunto de la empresa, incluidas las construcciones, adornos y logística, y no sólo al pabellón del Caya, como defiende el autor.

${ }^{35}$ Consúltense: LOZANO BARTOLOZZI, María del Mar, "Festejos y retórica: las capitulaciones de las bodas 
reales celebradas en Caia el año 1729", El arte en las cortes europeas del siglo XVIII, Madrid, Comunidad de Madrid, 1989; PIZARRO GÓMEZ, Francisco Javier, "Doña Bárbara de Braganza y el fausto cortesano en las fiestas reales", Portugal e Espanha entre a Europa e Além-Mar, IV Simposio Luso-Español de Historia del Arte, Coimbra, 1992.

${ }^{36}$ Cfr. TEDIM, José Manuel Alves, Festa régia no tempo de $D$. João $V$. Poder, espectáculo, arte efémera, Tesis doctoral, Oporto, Universidad Portucalense Infante D. Henrique, 1999, vol. 1, pág. 288-311.

${ }^{37}$ Cfr. ídem, íbidem, vol. 1, pág. 291 y 301-302.

${ }^{38} \mathrm{Cfr}$. NATIVIDADE, Fr. J. da, ob. cit., pág. 165-166.

${ }^{39}$ Cfr. TEDIM, J. M., ob. cit., vol. 1, pág. 301.

${ }^{40}$ Cfr. Consúltese TEIXEIRA, José de Monterroso, O Paço Ducal de Vila Viçosa. Sua arquitectura e suas colecções, Lisboa, Fundación de la Casa de Braganza, 1983, pág. 95-103.

${ }^{41}$ Cfr. NATIVIDADE, Fr. J. da, ob. cit., pág. 198-199. Consúltese tb: SOUSA, D. A. C. de, ob. cit., tomo VIII, pág. 154-155; BEIRÃO, C., ob. cit., pág. CXXVIII-CXXIX.

${ }^{42}$ Cfr. NATIVIDADE, Fr. J. da, ob. cit., pág. 197-203; FERRÃO, Leonor, "Custódio Vieira", PEREIRA, José Fernandes (dir.), Dicionário da Arte Barroca em Portugal, Lisboa, Presença, 1989, pág. 522

${ }^{43}$ Cfr. MECO, José, "Tectos", Do Palácio de Belém, Cat., Lisboa, Presidencia de la República, 2005, pág. 415-421; ESPANCA, Túlio, Inventário Artístico de Portugal, VIII, Distrito de Évora (concelhos de Arraiolos, Estremoz, Montemor-o-Novo, Mora e Vendas Novas), Lisboa, Academia Nacional de Bellas Artes, 1975; COELHO, António Borges, MARQUES, Gustavo, Vendas Novas, história e património, Vendas Novas, CMVN, 1991.
${ }^{44}$ En realidad, según la información facilitada por Fr. J. da NATIVIDADE, "Havia [en el palacio]sete quartos de três cazas cada hum, mui ricamente adereçados para a accomodação do Emminentissimo Cardeal, D. Nuno da Cunha e Ataíde, e do Senhor Patriarca $D$. Thomas de Almeida. Pelo que respeitava ao estado do Sereníssimo Príncipe do Brazil, e da Senhora Princeza das Astúrias, tinha cada hum destes dous Senhores, neste luzidissimo Palácio, Casa de docel, gabinete, e câmara. As Officinas, e tudo mais pertencente ao serviço da Magestade da Senhora Rainha, cahia para a parte esquerda do Palácio" (ob. cit., pág. 197 y 200). Pero el cronista compone su obra a años de distancia, a partir de la memoria y el conocimiento teórico facilitado por el plano,"a planta que temos em nossa mão". Y se sabe, v.g., que el Patriarca D. Tomás tomaría un camino distinto y no pernoctaría en el palacio. Solo en las dependencias del lado izquierdo del atrio (correspondientes a los aposentos superiores del Rey, lo cual se deduce por saber que los de la Reina se situaban en la parte izquierda) se conservan techos pintados, más toscos, de hecho, en cuanto a pintura, $y$, como se ha mencionado, más esbozados que acabados. Así, y después de lo que sabemos sobre el desarrollo del proceso del intercambio de las princesas y de la precipitada decisión de trasladar a la frontera las dos cortes, es posible que sólo estuviera prevista la decoración de los aposentos superiores, destinados a los príncipes, improvisándose después, ante la necesidad de alojar a los reyes, nuevo aposento en la planta baja con ese destino. Habrá sido ocupado, a la ida, por Bárbara y, a la vuelta, por D. José, puesto que Mariannina, dada su edad, compartiría durante años estancias inmediatas a los aposentos de la Reina, lo que facilitaría la distribución.

${ }^{45} \mathrm{Cfr}$. TAXONERA, L. de, ob. cit., pág. 169.
${ }^{46} \mathrm{Cfr}$. idem, ibidem; BARRENE-

CHEA, M. T., ob. cit., pág. 44.

${ }^{47}$ Consúltense las notas 10 y 11 anteriores.

48 Archivo Histórico Nacional, Madrid, Estado, 754.

${ }^{49} \mathrm{Cfr}$. BARRENECHEA, M. T., ob. cit., pág. 44-45.

${ }^{50} \mathrm{Cfr}$. ídem, íbidem, pág. 45.

${ }^{51}$ Cfr. ídem, íbidem, pág. 238.

52 Triunfo Elvécio, BME, Ms. 3203-3205 (TEDIM, J. M., Festa Régia..., pág. 315-317).

${ }^{53}$ Cfr. PÉREZ CAMINERO, R., ob. cit., pág. 78.

54 Archivo Histórico Nacional, Madrid, Estado, 754.

55 PIZARRO GÓMEZ, Javier, "Doña Bárbara de Braganza...", pág 69. Consúltese tb. TEDIM, J.M., "O triunfo da festa barroca...", pág. 180182.

${ }^{56}$ Cfr. PIMENTEL, A. F., "Ascensão e queda de António Canevari...".

${ }^{57} \mathrm{Cfr}$. ídem, íbidem.

58 Archivo Histórico Nacional, Madrid, Estado, 2461 - 1.

${ }^{59}$ Cfr. PIMENTEL, António Filipe, "António Canevari e a Torre da Universidade de Coimbra, Artistas e Artífices e a sua mobilidade no mundo de expressão portuguesa", Actas, VII Coloquio Luso-Brasileño de Historia del Arte, Oporto, Facultad de Letras de la Universidad de Oporto, 2005, pág. 49-58.

${ }^{60}$ Cfr. PIMENTEL, A. F., "Ascensão e queda de António Canevari...".

${ }^{61}$ Cfr. TEIXEIRA. J. M., ob. cit., pág. 60.

${ }^{62}$ Cfr. CARVAlHo, Ayres de, $D$. João $V$ e a arte do seu tempo, Lisboa, 1962, vol. II, pág. 368.

${ }^{63}$ Cfr. NATIVIDADE, Fr. J. da, ob. cit., pág. 180.

${ }^{64} \mathrm{Cfr}$. ídem, íbidem. 


\title{
TEXTO ORIXINAL
}

\author{
A "Troca das Princesas": arte e política nas festas do casamento de \\ Fernando de Bourbon e Bárbara de Bragança
}

António Filipe Pimentel

Universidade de Coimbra

Movidas pelo insólito aparato, a um tempo diplomático e cerimonial (com as inerentes consequências estéticas) que, em Janeiro de 1729, rodeou, na fronteira luso-espanhola do Caia, entre Elvas e Badajoz, a designada troca das princesas (das infantas Bárbara de Bragança e Mariana Vitória de Bourbon, filhas de D. João V de Portugal e de Filipe $V$ de Espanha, destinadas a consorciarem-se com os herdeiros dos reinos vizinhos: o Príncipe das Astúrias, Fernando de Bourbon e o Príncipe do Brasil, D. José de Bragança), tanto a historiografia como a historiografia artística de ambos os países se vêm de há muito interessando pela matéria, acumulando, por conseguinte, vasta informação. Apesar disso, a atávica tendência dos investigadores de ambas as disciplinas (História e História da Arte) para o isolamento das respectivas investigações, bem como a emergência de novos elementos, parece justificar uma revisita deste velho tema, com vista a operar o cruzamento dos dados fornecidos pelas duas plataformas de observação e estudo, bem como a incorporar os novos elos, assim produzindo uma visão integrada de um processo que, em qualquer dos ângulos, reveste inquestionável interesse: sendo que a cada um deles se revela útil o conhecimento dos dados carreados pelo outro.

A proposta do duplo consórcio dos herdeiros dos tronos peninsulares seria feita aos monarcas portugueses por parte dos seus pares espanhóis (e o facto é relevante), em Março de 1725, no seguimento do dramático repúdio, por iniciativa do novo chefe do governo francês, o Duque de Bourbon, de Mariana Vitória (Mariannina), que em Versalhes residia desde 1722, destinada a consorciar-se com o jovem Luís XV'. Mariana partira então, com quatro anos incompletos, trocada na llha dos Faisões, no rio Bidasoa, em Janeiro, entre alardes de pompa, com Mademoiselle de Montpensier, Luísa Isabel de Orleáns, filha do Regente e destinada a consorciarse com seu irmão Luís²: o efémero Rei Luís I, quando, dois anos mais tarde, Filipe $V$ abdicar, até ser forçado a regressar ao trono, pela sua morte, oito meses depois. Agora, Mariana contava sete anos, D. José, seu putativo noivo, onze e Fernando e Bárbara, respectivamente, doze e catorze.

O programa da dupla aliança na Casa de Bragança inscreve-se, pois, directamente no quadro genérico da consabida e complexa estratégia matrimonial permanentemente desenvolvida por sua mãe, Isabel Farnésio e, de modo particular, no da urgente desafronta da juvenil princesa: e, por tabela, da Monarquia castelhana. Casar rapidamente a repudiada infantinha num trono minimamente lustroso —e o português de D. João V era-o certamente - seria o motor central do duplo enlace: o de Fernando (o enteado) e Bárbara viria por tabela, deixando livres para os infantes, filhos da Rainha, outros mais lustrosos partidos europeus: como escreveria Alfonso Danvila, "Tales fureron los célebres matrimonios portugueses que tanto dieron que hablar y tantas interrupciones y contrariedades sufrieron hasta celebrarse. Ninguna ventaja conseguimos con ellos, como no fuera el hacer ceñir una corona á la Infanta desairada por Luís XV. El príncipe Fernando fué sacrificado con ellos"3.

Do ponto de vista português, porém, a proposta revestia igualmente oportunidade: não tanto no âmbito do apaziguamento das velhas questões que, desde o tratado de Utreque, minavam as relações dos dois países e haviam chegado a ditar preparativos bélicos (na essência, o pagamento, nunca efectuado, da indemnização a que Espanha fora condenada no seguimento da Guerra da Sucessão e a delimitação, sempre pendente, das fronteiras dos domínios ibéricos na América do Sul: o que implicava a devolução por Espanha da colónia do Sacramento), mas porque igualmente Portugal se considerava ofendido com a nação gaulesa, na sequência do episódio da exclusão portuguesa do congresso de Cambray, em 1720, envenenada pelo esse outro protocolar (mas não inocente) que havia conduzido à retirada de Lisboa do abade Livry, ministro de Luís XV, justamente 
em Janeiro de $1725^{4}$. E a tudo isto acresceria, na verdade, a honra que resultava da perspectiva de ver sentar Bárbara num dos tronos de maior relevo entre as potencias católicas de primeira grandeza.

A proposta seria, pois, acolhida com claro entusiasmo por parte do Rei de Portugal, não fora vir embrulhada em condicionantes que, logo de início, fariam inquinar a respectiva negociação: basicamente, a constituição paralela de uma liga ofensiva e defensiva ${ }^{5}$, a estabelecer entre as duas Coroas, que arriscaria fazer arrastar a Monarquia portuguesa para o verdadeiro vespeiro em que, por então, se convertera boa parte da Europa e onde as ambições da Rainha de Espanha de obter coroas para os restantes filhos detinham substantiva parte. Desígnio que se confrontava com a inabalável neutralidade assumida por D. João $V$ em matéria de política externa .

Desse modo e ao mesmo tempo que, em Maio, la petite Reine (como era tratada na Corte de Versalhes), regressava a Espanha, seriam as negociações empreendidas entre as duas cortes, não através dos canais formais dos respectivos agentes diplomáticos, mas de ministros plenipotenciários nomeados ad hoc, cada um dos quais se empenhando em fazer vingar a estratégia individual do seu senhor: pela parte portuguesa José da Cunha Brochado, experimentado mas avançado em anos, a quem incumbia a espinhosa missão de alcançar o isolamento da proposta matrimonial em relação ao projecto da liga em que vinha envolta. Tarefa, porém, dificultada pela ambição de $D$. João $V$ de, por seu turno, aproveitar o ensejo para ver resolvidas as velhas pendências arrastadas desde Utreque (a que acresciam ainda outras várias questões de menor monta).

Neste contexto, haverá que aguardar por 2 de Outubro para que, ao cabo de intrincadas negociações de ambas as partes, que pruridos cerimoniais ainda mais tolhiam, se procedesse, enfim, em Madrid, ao anúncio público da ratificação dos artigos preliminares dos dois contratos matrimoniais, secundada em Lisboa oito dias depois. Ocasiões que dariam azo aos usuais festejos, mas onde o quadro estritamente oficial das celebrações na Corte castelhana contrastaria com o regozijo exibido em Portugal, seja no plano da adesão popular, seja no das festas organizadas pela Corte e pelo embaixador espanhol, Capecelatro, entre 10 e 13 desse mês?.

Em consequência do ajuste dos enlaces, procederiam os monarcas à nomeação dos respectivos embaixadores extraordinários, destinados a formalizar, em uma e outra corte, o pedido de casamento: o de Espanha, marquês de los Balbases, em Janeiro ainda; o português, marquês de Abrantes, a 2 de Fevereiro de 1726. Apesar disso, a partida para as mútuas missões seria suspensa até finais do ano seguinte de $1727^{8}$ e, durante o longo período que medeia, a Corte portuguesa não esconde o nervosismo que o compasso de espera lhe provoca, pressionando quanto pode no sentido da formalização dos esponsais (não sem deixar, contudo, de dificultar, por sua vez, a gestão diplomática, ao empenhar-se em iludir todo e qualquer compromisso político-militar, insistindo, porém, na resolução das questões pendentes).

Por seu turno, em Madrid, a Corte de Filipe $V$ passava então por um dos períodos negros que ensombrariam amiúde o seu longo reinado. Com efeito, à crise política que conduziria à destituição do ministro Riperdà, em Maio de 26; à iminência da guerra com França, em Julho, que arrastaria, por sua vez, a queda em desgraça do valido da Rainha, marquês de Grimaldo; ao início da tensão com Inglaterra, frente a Gibraltar, em Julho de 27, que mais não faria que agravar-se nos seis meses seguintes (tudo mesclado das complexas manobras de Isabel Farnésio em relação à Áustria, com vista a casar os seus filhos Carlos e Filipe e a dotá-los de estados italianos e com França, na sequência ainda do caso de Mariannina), somava-se a saúde do próprio Rei, Filipe V, cuja instabilidade psíquica atingira um ponto crítico, tudo abandonando à gestão turbulenta da Rainha9 .

Finalmente, porém, conformadas ambas as cortes a deixar de fora da questão estrita dos enlaces as matérias políticas em que, de início, procurariam envolvê-las, tem lugar, em La Granja, a 14 de Setembro, a assinatura dos capítulos matrimoniais de Mariana Vitória e D. José, a que se seguiriam, a 1 de Outubro, em Lisboa, os de Bárbara e Fernando, em função do que se fariam então as entradas públicas dos embaixadores: a de Abrantes dia de Natal, a de Balbases a 6 de Janeiro, em ambas se alardeando a maior pompa (com maior envolvimento público e popular, como sempre, na Corte portuguesa), numa emulação de fausto que visa preservar a mútua dignidade das duas monarquias. E é então que fica estabelecido que as duas cortes se comprometerão a conduzir as noivas, simultaneamente, à fronteira comum, onde se realizariam as entregas ${ }^{10}$ : o desagravo da afronta feita a Mariannina passava pela reprodução, em moldes de igual dignidade, da cena da llha dos Faisões, onde fora trocada a caminho de França, e nesse sentido se comunicara já ao corregedor de Badajoz, em 19 de Setembro, a decisão régia de realizar aí a dupla boda hispano-portuguesa"1.

Em consequência, Isabel Farnésio encomenda vestidos em Paris, além das jóias de preceito a oferecer à nova Princesa das Astúrias, para a constituição de cuja casa de igual modo se iniciam diligências' ${ }^{12}$, enquanto, por seu turno, também a Corte lusitana se abastece na capital francesa de todo o tipo de adereços com destino aos esponsais (desde logo de artigos de viagem, meios de transporte, selas, telizes, etc.), além, naturalmente, do enxoval da própria Bárbara, constituído em termos da "maior grandeza que se pode imaginar"13. É, porém, a recomendação 
feita pelo secretário de Estado, Diogo de Mendonça Corte-Real, ao agente português, Francisco Mendes de Góis, a 19 de Outubro, de que as sucessivas encomendas se forneçam de artigos "ja feitos (porque a brevidade do tempo não dá lugar a que se faça) ${ }^{m 14}$, o melhor indicador de que os consórcios finalmente se precipitavam.

Efectivamente, com a entrada pública de Los Balbases, em 6 de Janeiro de 28, para formalizar o pedido da infanta portuguesa, tudo indicava começar enfim, para o duplo enlace, a contagem final. No dia 10 imediato outorgam-se, em ambiente de gala e regozijo da Corte e delírio popular, as capitulações matrimoniais e nesse e no seguinte (em que, na Basílica Patriarcal, se procede ao casamento da Infanta, actuando o Rei seu pai em representação do noivo ausente), iluminar-se-ia o Terreiro do Paço com as máquinas pirotécnicas engendradas por António Canevari, arquitecto romano acabado a arribar à Corte lusitana, onde fazia a primeira demonstração dos seus talentos: representando, a da primeira noite o Templo de Diana —enorme e clássica edícula, escoltada de colunas e sobrepujada pela fama, enquadrando a figura da deusa e assente sobre um rochedo- e a da segunda a gruta do Monte Latmo, com as três Graças: esta de cunho essencialmente naturalista, sob a forma de uma caverna rochosa, abrigando as ninfas, ao topo da qual Diana, recostada numa nuvem, contemplava o pastor Endímion ${ }^{15}$. E os festejos prolongar-se-iam até 13, com o panegírico de ocasião, por intermédio da Academia Real da História' ${ }^{16}$.

Subitamente, porém, agrava-se dramaticamente o estado de saúde de Filipe V: nesse mês de Janeiro, não somente a demência do monarca atingiria um ponto que se reputava irreversível, como chegaria a temer-se pela sua vida, com as consequências inerentes, seja do ponto de vista da programação condigna das cerimónias matrimoniais, seja, muito particularmente, no que se relacionava com o próprio poder de Isabel Farnésio, compelida a admitir o enteado Fernando ao conselho de Estado e antevendo-se já, com os filhos, projectada num destino obscuro - receios que a tentativa de abdicação que o monarca (uma vez mais) consegue levar a cabo, mais não faz que confirmar ${ }^{17}$. A oportunidade de Fernando ser acometido de varíola, em Maio, resolvia de momento o problema político ${ }^{18}$ (poderia, até, resolvê-lo em definitivo...), mas, sobretudo, introduzia nova perturbação na matéria dos enlaces, que, tudo indicava, não lograria adiantar-se a curto prazo, tendo-se, aliás, mandado regressar o embaixador Balbases, uma vez cumprida a específica missão de que fora investido ${ }^{19}$.

Apesar disso, em fins de Maio, recebiam as autoridades de Badajoz ordens —infaustas para o estado das finanças locais - de proceder ao corte de 1.500 troncos para a construção dos estrados onde tomaria lugar a comitiva espanhola sobre o rio Caia, por ocasião da troca das princesas ${ }^{20}$. Mas nada de efectivo seria adiantado na matéria, no período imediato, a não ser que, do lado português, empreendera $D$. João $V$, já no mês de Fevereiro, a construção de um palácio em Vendas Novas, destinado a alojar as comitivas régias no caminho e no regresso da fronteira: obra cometida (et pour cause) a um engenheiro militar, José da Silva Pais, que na América culminaria, mais tarde, uma brilhante folha de serviços e que alcança edificá-lo —-bem como a outros cómodos que se providenciariam ao longo do caminho- no lapso inverosímil de dez meses ${ }^{21}$. Enquanto isso, ainda em Março e talvez como forma de pressão política (atentos os vínculos familiares que, mau grado o episódio de Mariannina, uniam os Bourbons de França e Espanha) os Reis de Portugal comunicam oficialmente aos soberanos gauleses (Luís XV casara entretanto com Maria Leczinska) o duplo enlace dos seus filhos ${ }^{22}$.

É então que, subitamente, no fim do verão, os Reis de Espanha dão a conhecer o seu propósito de acompanhar a infanta até à fronteira: e assim o comunicam para Badajoz, a 20 de Setembro ${ }^{23}$. A decisão, insólita e que obrigaria os soberanos portugueses a igual correspondência ${ }^{24}$-e estaria na origem do extraordinário espectáculo de emulação de pompa em que iria converter-se a troca das princesas - constituía, ao que tudo indica, manobra de Isabel, destinada a afastar Filipe de Madrid e a proteger-se dos seus intentos contínuos de abdicação, ao mesmo tempo que do vespeiro de rumores que, nesse quadro aparente de fim de reinado, Ihe minavam o exercício do poder. Não deixava, contudo, de introduzir um factor novo de complicação, pela incapacidade manifesta do monarca espanhol, debilitado e por completo demente, de empreender uma tal expedição. Porém, como por milagre, a notícia chegada a Madrid, em Novembro, de ter Luís XV (ainda sem herdeiro), contraído a temível varíola, produziria um súbito e aparentemente completo restabelecimento em Filipe, desdobrado agora em frenética actividade, com vista a reclamar a respectiva coroa: situação que Isabel Farnésio rapidamente aproveitaria para anunciar, a 17 de Dezembro, a partida da Corte para a fronteira portuguesa em 7 de Janeiro do novo ano de $1722^{25}$. Quando, justamente, se cumpriam quatro anos sobre o episódio infausto da llha dos Faisões...

Conhecida a notícia em Lisboa, inopinadamente, por comunicação oficiosa do embaixador Capecelatro, em 19 de Dezembro (a 20 chegaria a carta oficial e, a 22, a do nosso embaixador, marquês de Abrantes) ${ }^{26}$, iniciamse, em ambas as capitais, em frenesi, os preparativos da jornada, coordenados na parte portuguesa, com mão de ferro, pelo duque de Cadaval e estribeiro-mor, D. Jaime Álvares Pereira de Melo, apoiado pela logística militar27. 
Por parte de Espanha, onde a Corte, na sua maioria, se conserva alheia à encenação engendrada pela soberana —que apostará essencialmente, no aparato militar-, uma verdadeira multidão se projectará sobre a margem do Caia; do lado português serão bem menos (cerca de 2000 , a crer nas fontes ${ }^{28}$ ) e a componente bélica essencialmente ornamental, mas, em contrapartida, o aparelho áulico figurará em pleno e aposta-se, essencialmente, na sua apresentação.

Como quer que fosse, era extraordinária a expectativa no dois círculos cortesãos em relação e um espectáculo em absoluto destituído de qualquer precedente: "Segurovos — escrevia de Madrid o marquês de Abrantes ao conde de Tarouca, também ele diplomata, em 27 desse mês- que com razam estão todos em expectação de ver da nossa p. ${ }^{\text {te }}$ o mais opulento, e lustrozo espectáculo, que jamais deu Portugal de sy; e desta, posto que a ostentação, quanto ao luxo, não seja tanta, não ha duvida que vay hua numeroza corte, porque sem haver grande, que se rezolva a accompanhar o seu Soberano, salvo o Conde de las Torres, os officiaes da Caza Real, os officios, e os que d'elles dependem, se estima que serão o melhor de dezasseis mil pessoas: vos acabais de ver hua jornada Cesarea, mas cuydo que ella não importava tanto, como estas duas Regias"29.

Preocupada, essencialmente, em atingir rapidamente Badajoz, onde entraria a 16 de Janeiro, Isabel Farnésio estrutura a jornada em dez etapas, por completo desprovidas de cerimoniais locais. Não assim a Corte portuguesa, cujo percurso tentaria conciliar o objectivo central de alcançar Elvas com a dignidade inerente à exibição real. Com esse fito, dois cortejos sucessivos se organizariam (o masculino: do Rei, Príncipe do Brasil e Infantes, que arrancaria de Lisboa a 8 de Janeiro; e o feminino: da Rainha, Princesa das Astúrias e infantinho D. Pedro, que abalaria a 9), em ambos se observando idêntico ritual, a despeito do rigor do inverno e do agravamento contínuo das condições meteorológicas, que apenas no final abrandariam ${ }^{30}$ : partida, em bergantins, do Paço da Ribeira; desembarque e orações no Mosteiro da Madre de Deus; travessia para Aldeia Galega e pernoita; continuação para Vendas Novas, com dormida no palácio novo; seguida para Évora (e dormida), com recepção prévia em Montemor-o-Novo; depois Vila Viçosa (com dormida) e, finalmente, Elvas, que D. João V, de igual modo, atingiria a 16, duas horas antes que, na praça fronteira, as salvas de ordenança anunciassem a entrada o seu par espanhol.

Apesar disso, as entregas não se fariam sem percalços. De facto, certamente sob os auspícios dos desejos de Isabel Farnésio de concluir a cerimónia quanto antes, Filipe $V$ comunica ao soberano português o seu desejo de proceder à troca no dia imediato, 17. Todavia, fosse por entender que os Reis de Espanha desejariam poder conceder-se algum descanso antes da função, fosse porque a boa ordem do aparato que ambicionava poder ostentar (essencialmente curial e, logo, mais complexo que o militar espanhol -e, de resto, eficazmente alcançado, a crer no testemunho do abade Montgon, ao escrever que "la pompe avec laquelle il vint au pavillon, surpasse tout ce qu'on peut dire" ${ }^{\prime \prime 1}$ ) exigiria ainda algum ensaio prévio, D. João $V$ é colhido de surpresa, sendo forçado a ordenar uma marcha precipitada para o Caia que, porém, já não logra alcançar a comitiva castelhana, que empreendera o retorno a Badajoz. Após justificações e as devidas conferências preliminares sobre o meticuloso cerimonial a observar, por parte dos secretários de Estado das duas potências, apraza-se, finalmente, o dia 19 para a almejada troca, no sumptuoso pavilhão adrede construído e onde, de facto, por efeito do meticuloso protocolo ajustado, "En un mot, l'égalité des deux parts avoit été scrupuleusement observe", como, de novo, resumiria Montgon ${ }^{32}$.

As duas famílias reais e respectivas comitivas, de resto, haveriam ainda de voltar a encontrar-se, por mais duas vezes (a 23 e a 26), em ambiente, agora, de relativa informalidade (particularmente), antes de despediremse definitivamente: a portuguesa para o regresso a Lisboa e à entrada solene dos novos Príncipes do Brasil; a castelhana rumo a Sevilha e ao famoso lustro em que, por quatro anos, Isabel Farnésio lograria isolar Filipe $V$ dos mentideros de Madrid ${ }^{33}$. Para trás, porém, e articulado directamente com este episódio a todos os títulos excepcional, quedava-se, sobretudo do lado português (fruto da dignidade que D. João $V$ se esforçou, em todo o momento, por imprimir ao acto: a despeito da difícil articulação com o ritmo peculiar do processo decisório por parte da Monarquia castelhana, ao qual, forçosamente, teria de ajustar-se), todo um conjunto de empreendimentos relevantes do ponto de vista da História da Arte (por vezes mesmo no domínio estrito da cripto-História da Arte), que absorveriam, certamente, parte substantiva dos sete milhões de cruzados que, a fazer fé nas fontes, custaria ao monarca a sumptuosíssima excursão ${ }^{34}$.

E, neles, avultam certamente o vasto casarão de Vendas Novas e o pavilhão do Caia (em relação ao qual, justamente, emergem hoje novos elementos). A sua correcta apreciação, contudo e a contextualização a que naturalmente obrigam do ponto de vista do conhecimento já consolidado sobre as estratégias do mecenato artístico do monarca lusitano, impõem, necessariamente, que se tenham em conta as estritas contingências do contexto histórico — conturbado e também ele realmente extraordinário- em que haveriam de gerar-se.

Na verdade e para além das consequências directas, nunca sistematicamente recenseadas, que a passagem do munífico monarca geraria no que respeita ao património local dos principais núcleos urbanos que pontua- 
vam o itinerário da função, uma espessa nebulosa paira, sobretudo, sobre o barroco regional dos festejos municipais, absolutamente ausente na parte espanhola, por força do inopinado anúncio da partida e da estratégia régia de atingir o quanto antes Badajoz, e que aqui mesmo adquiriam tímida expressão. De facto, é somente em Sevilha, para onde, seguidamente, a Corte se traslada, que surpreendemos a sua total exibição, num quadro genérico onde não deixa de causar surpresa a capacidade de improviso demonstrada ${ }^{35}$.

Do lado lusitano, todavia, evocam as fontes a ornamentação de Montemor-o-Novo (quatro arcos triunfais, realizados pelos artistas locais Francisco Salas, Francisco de Cardenas, Sebastião Mendes Oliveira e Martinho Francisco), de que não quedaria ilustração, outro tanto sucedendo com Évora (um arco, na rua da Selaria, edificado pelos ourives de ouro e prata; outro na rua da Anca, dos mercadores; outro ainda, na rua da Lagoa, dos oficiais das bandeiras de S. José e S. Jorge, balizando o percurso até à Sé), com Vila Viçosa (dois arcos triunfais e armação das portas e fontes do recinto urbano) e, finalmente, com Elvas (arcos na rua de Olivença, na rua da Carreira e na porta da Praça ${ }^{36}$, surpreendendo-se na documentação os efeitos do controlo real, no sentido da normalização e decoro, seja do cenário, seja dos cerimoniais, em relação a possíveis ingerências da tradição vernácula. Assim é que, em Évora, o cabido, mobilizando embora os seus recursos, se abastece em Lisboa para a ornamentação da Sé, ao mesmo tempo que, em Elvas, a vereação recomenda expressamente que "não houvesse danças ridículas como em outros tempos haviam", impondo que, no trajecto conducente à catedral, a ornamentação de portas e janelas particulares se faça unicamente com recurso a sedas ${ }^{37}$.

Na verdade, força da intempestiva decisão de partir para a fronteira a 6 de Janeiro tomada pela Corte espanhola e apenas transmitida, fosse a Badajoz, fosse a Portugal, a escassos dias do Natal, a comunicação formal, por seu turno, às diversas cidades onde haveria de passar a comitiva nacional, não seria realizada antes de 2 de Janeiro ${ }^{38}$ : pelo que pode bem adivinhar-se a azáfama que as tomou. Contudo, sendo o Caia, por tradição, o ponto de trânsito das princesas casadoiras entre os dois países (logo, consabidamente, o trajecto a seguir pelas duas noivas régias, independentemente das proporções que a troca com o tempo adquiriria) e ante a aparente iminência da celebração dos consórcios, no seguimento da assinatura das capitulações matrimoniais no Outono de 1727, desde Maio de 28 que Elvas (e outro tanto terá sucedido em toda a parte) havia sido notificada pelo governador de armas da província do Alentejo da ordem real de fazer ornamentar a urbe e as "mais terras por onde houvessem de passar as Sereníssimas Senhoras Princesas deste reino de Portugal e Castela"139.

Com o ciclo das entregas, aliás, se relacionarão, igualmente, as obras dinamizadas por $D$. João $V$ no imponente solar dos seus maiores —o Paço Ducal de Vila Viçosa-, onde havia estado em 1716 e dificilmente voltaria, certamente, não fora a obstinação da soberana castelhana em conduzir a Corte a Badajoz e em superar em exibição de fausto o episódio da llha dos Faisões: concretamente a construção da nova cozinha e respectivos anexos (cuja contratação se encontra documentada em 1728), mas, especialmente, o programa decorativo da Sala dos Tudescos, com a série ducal pintada por Duprà e cuja cronologia se fixaria, na tradição historiográfica, ao redor $1725^{40}$ : datação (média) que não repugna aceitar, a partir da análise iconográfica dos retratados (do próprio Rei, de Bárbara e de D. José). Ou seja, em concomitância com as propostas matrimoniais.

Espaço central ocupa, todavia, o designado Palácio de Vendas Novas, edificado com o objectivo essencial de providenciar guarida às régias comitivas no ponto médio do trajecto entre Lisboa e Évora. Iniciado em Fevereiro de 1728 e concluído "por todo o mez de Dezembro" —como diria o cronista "só não pôde caber no tempo, acabar de pôr a ultima mão em alguma pequena porção, que ficou por repartir, em desenho" ("El-Rey de Portugal añade à su grandeza la de hacer milagros", exclamaria Montgon à sua vista) - nele, a acreditar nas fontes, se empregariam, sob o comando disciplinar de Silva Pais, cerca de 2000 homens, importando a obra num milhão de cruzados, entre estrutura e ornamentação ${ }^{41}$. Essencialmente uma vasta e desadornada mole, de dois pisos e carácter funcional (não obstante as fontes declinarem também, em associação a Silva Pais, o nome do Arquitecto Custódio Vieira), provido de alas térreas, destinadas a albergar as oficinas, das quais a do extremo direito remata na capela, permanece globalmente desconhecido, do ponto de vista da investigação: vítima da negligência e do inapropriado uso militar a que seria votado desde o século XIX $X^{42}$.

Apesar disso, sobrevive nele ainda um conjunto assinalável —e em extremo interessante- de tectos pintados sobre tela (por óbvias questões de rapidez: os do piso térreo, aliás, no essencial simplesmente esboçados), em relação aos quais seria mesmo estabelecido parentesco formal com obras paralelas do Paço de Belém (e avocado o nome de Vitorino Manuel da Serra, referido pelos panegiristas como o introdutor em Portugal do "primoroso ornato francês") ${ }^{43}$, além do esplêndido retábulo da capela e, na essência, a repartição interna: com o átrio chamado dos Tudescos e a divisão canónica, entre as alas do Rei e da Rainha (correspondendo aquelas, ao nível térreo, aos aposentos da Princesa das Astúrias e do Príncipe do Brasil|4).

Em tudo isto, porém, ocupa o lugar central, como não poderia deixar de ser, a designada casa das entregas: o pavilhão que, sobre o rio Caia, deveria albergar o ponto culminante da função, servindo de cenário ao confronto 
final entre as duas Cortes, em emulação de magnificência. Dele se conhece, há muito, hum projecto de planta, alçado e corte, conservado no Arquivo Histórico de Madrid, além, naturalmente, das descrições exaradas pelos cronistas. Contudo, a emergência de dois desenhos novos pertencentes ao mesmo fundo documental e respeitando à casa das entregas, um, e outro aos trabalhos de engenharia a que obrigou a determinação, alimentada pelas duas Coroas e que Montgon reportaria, de respeitar escrupulosamente, no acto cerimonial, l'égalité des deux parts, impõe que nos detenhamos mais sobre a matéria, a começar pelo último tema, o qual, na verdade, possui maior interesse do que, aparentemente, se poderia imaginar.

Com efeito, o local deputado para a troca sofrera substanciais alterações desde que, em 1543, aí se entregara, pela última vez, uma noiva real: concretamente, D. Maria de Portugal, filha de D. João III e D. Catarina de Áustria, destinada a consorciar-se com o futuro Filipe II de Castela $a^{45}$. Efectivamente, ainda que tratando-se, na prática, de um modesto riacho, era, com frequência, sujeito a cheias de grandes dimensões, que, com o tempo, o tinham feito abandonar o leito primitivo, correndo agora, nas imediações da estrada Elvas/Badajoz, por terras de Espanha, servida esta por ponte de madeira: enquanto, sobre a antiga madre, subsistia abandonada e coberta de areia e terra a ponte de pedra original ${ }^{46}$. Neste contexto e provavelmente no seguimento da assinatura, no Outono de 1727, das capitulações matrimoniais e da decisão nelas contida de proceder à condução simultânea das duas noivas à fronteira, recreando, em benefício de Mariannina, a cenografia da llha dos Faisões ${ }^{47}$, Feliciano de Bracamonte, comandante geral da província de Badajoz, receberia o encargo de realizar um estudo das condições da ponte e do rio e um projecto das obras a realizar.

Nesse sentido e face à necessidade de fazer respeitar, na insólita e régia função, l'égalité des deux parts, assentar-se-ia em aproveitar a ponte antiga, situada na raia entre os dois reinos. E tal impunha construir um dique, por forma a obrigar o curso de água a deslocar-se ao seu antigo leito fronteiriço, limpando e reparando a velha madre, pouco profunda e invadida pela vegetação, e, naturalmente, a consolidar e reparar a antiga ponte de pedra, que deveria servir de base a uma edificação de madeira, porém digna do evento que lhe cumpria albergar. Bracamonte enviaria ao seu monarca o plano correspondente (que se conserva no arquivo de Madrid ${ }^{48}$ ) e a estimativa dos custos da obra e respectiva duração: dois meses de trabalhos. Os quais seriam aprovados e, em função deles, teria lugar, na raia, uma entrevista com um enviado da Corte portuguesa. Esta, porém, desejosa sempre de imprimir a maior celeridade ao complexo e interminável processo da troca das princesas, responde ser mister obra mais breve, susceptível de concluir-se em vinte dias, contrapondo, com esse fito, a sugestão de uma ponte de barcas sobre o rio, para a passagem das duas comitivas, operando-se as entregas em pavilhão erguido sobre a margem.

Em vão: face à contingência de o acto poder vir a ter lugar em local indigno de tal acontecimento, contesta-se de Espanha estar-se em disposição de aguardar o que fosse mister. Neste contexto, ferido no seu orgulho régio, D. João $V$ contrapõe um novo plano, mais ambicioso e opulento ainda que o espanhol: ao qual contestam Filipe e Isabel nada ter a obstar, tudo se lhes afigurando pouco no tocante à dignidade dos seus filhos ${ }^{49}$. A obra arranca assim, deputando para ela, Portugal e Espanha, 500 homens cada, iniciando-se os trabalhos de limpeza do rio, construção do dique e reparação da ponte, a 10 de Maio de 1728 e prolongando-se até finais do mês de Setembro. Em simultâneo, preparar-se-iam os materiais para a casa, a qual, todavia, se decide não montar, face à aproximação do inverno, até haver ciência certa da data da troca das princesas ${ }^{50}$.

No que respeita ao pavilhão propriamente dito, são conhecidas, de há muito, as descrições averbadas pelas fontes, em particular a mais minuciosa, que reporta Frei José da Natividade, o cronista português do evento. Sabemos, assim, que este, por forma a garantir meticulosamente a obsessiva igualdade das partes, era constituído por "três Casas: as duas dellas collateraes, para cada hum dos Monarcas, nos seus domínios; e a do meio, arquitectada também com tal disposição que cada hum dos Monarcas tinha assento nos seus domínios, para a cerimónia das Reaes entregas". Natividade, todavia, presta essencial atenção ao esplendor da decoração interna, averbando apenas, quanto à estrutura do edifício efémero, ter ele noventa e oito palmos de área e ornar-se "a fachada exterior da Casa de Castella com as Armas Reaes daquella Coroa, e triunfavao semelhantemente na de Portugal, entre duas figuras allegoricas, as suas sagradas, e tantas vezes Triunfantes Quinas" ${ }^{\prime \prime 1}$. Porém, um poema manuscrito coetâneo, redigido, decerto, por um observador presencial, forneceria mais detalhadas informações.

Refere ele, com efeito, os "quatro cunhaes em que formavao / desta obra seus cantos magestozos / quatro figuras de fama celebravam / estes júbilos régios gloriosos", bem como que "As armas portuguezas que adornavam / em seu pórtico o ponto mais subido /duas regias figuras sustentavam IAtlantes deste ceo engrandecido", ou ainda que "Dois leões da Arcania eram quem davam / soberba a este pórtico luzido / que no mais na igualdade de modello / com o outro corria paralello / tendo mais cada pórtico a seu lado / duas janelas de igual grandeza / das que estava o palácio rodeado / todas feitas de igual custo a riqueza / o seu numero dellas bem contado / vinte e duas fazia em redondeza / (...) Nove janellas tinha em cada lado / que ocupavam de lado toda 
a parte". E, quanto ao esplendor dessa arquitectura de fingimento, não esquece de averbar que "O pórtico que tinha nesta entrada / era todo de talha mais subida / donde o ouro fazia mais sobradas / a soberana maquina erigida", que as janelas eram "em caixilho vermelho ajiletado / de ouro puro a vidraça transparente / com simaIhas azuis de pedra fina", etc. 52

Por seu turno, do lado castelhano, onde as fontes seriam mais lacónicas, uma minuciosa relação das festividades organizada pelo Ayuntamiento de Badajoz descreve nestes termos a estrutura do pavilhão: "a espenssas del Rey Ntro Señor y de S. M. lusitana, se favricó una sumptuosa cassa de Madera que constava de três galerias tan capaces que ocupavan quattro de los primitibos arcos del médio de suerte que el segundo salon comprehendia de médio a me[dio] la rivera de forma que la una sala y la mitad del zentro dividia el término de Castilla y la otra y media restante el de Portugal ocupando su território conque unida, cada mitad, contraria la de la parte de Castilla, de quatro valcones y médio, y otros tantos la de Portugal; conque el todo del Palazio por cada uno de los costados, tenia nuebe balcones con três puertas y ventanas de cristales finos, y toda arquitectura pintada de fingidas piedras [...] Piedra azul, Piedra encarnada y Piedra verde..." ${ }^{\prime 53}$

Deste pavilhão é conhecido da historiografia, de há muito, um belo desenho, composto de planta, alçado e corte longitudinal, realizado pela parte espanhola, por intermédio dos engenheiros Filipe Crame e Juan Frentchqueson, numa arquitectura digna e sóbria, que segue os cânones clássicos da arquitectura militar ${ }^{54}$ (e a respeito do qual foi já vincado ser "obra concebida con un fin eminentemente práctico"s5). Suscita ele, contudo, óbvios problemas de correspondência com as descrições —aliás concordes- averbadas pelos memorialistas, designadamente no que respeita ao número de janelas ostentado pelos pavilhões (seis por lado e que estes afirmam serem nove, perfazendo, com as duas que, em cada topo, flanqueavam as entradas —e seriam quatro nesteum total de vinte e duas) e mesmo a aspectos decorativos, nomeadamente dos cunhais, onde, como diz o poema, "quatro figuras de fama celebravam / estes júbilos régios gloriosos": sendo que o desenho conhecido ostenta, nesse local, quatro obeliscos rematados por esferas. De igual modo, nada, nesse projecto, sugere o esplendor de talhas sobredouradas e fingidas piedras multicolores, de que se compunha o pavilhão segundo os seus cronistas (nele se ilustrando, antes, um fingimento de puro efeito de cantaria, ao serviço de um desenho, aliás, já proto-neoclássico) ao mesmo tempo que, ao ser de pura autoria castelhana (obra dos engenheiros militares Filipe Crame e Juan Frentchqueson) e, na verdade, sem ponto de contacto formal com a estética de Ludovice e com o que se conhece da de Canevari (que, pela parte portuguesa, colaborariam na função, tudo indicando, aliás, serem as festividades da troca das princesas a razão de fundo da deslocação deste último a Portuga $\left.\left.\right|^{56}\right)$, não poderia deixar de ser entendido pela historiografia lusa como de problemática interpretação, provavelmente ilustrativo de fase intermédia do programa ${ }^{57}$.

Porém, sabe-se agora que, em consequência do encargo cometido ao comandante geral da província de Badajoz, Feliciano de Bracamonte, muito provavelmente no seguimento da assinatura, no Outono de 1727, das capitulações matrimoniais e da correlativa decisão de proceder à condução simultânea das duas noivas à fronteira, de realizar um estudo das condições oferecidas pelo rio Caia e sua(s) ponte(s), elaboraria este, em conformidade, um projecto das obras a realizar, que incluíam o regresso do rio à sua antiga madre, obtido por intermédio da construção de um dique, aproveitando-se para assentamento da casa das entregas a ponte antiga, a cuja reparação se procederia. E sabe-se também que o projecto, aprovado pela Corte de Madrid, colheria a oposição da parte portuguesa, empenhada em imprimir à troca a maior celeridade, razão porque contrapõe uma outra ideia, susceptível de estar concluída em vinte dias. Mas que esta última se defrontaria com a obsessão cenográfica de Isabel Farnésio, empenhada em desagravar a pequena Mariannina e impedir que o seu novo casamento tivesse menos brilho que esse outro que começara na esplêndida jornada da llha dos Faisões. Razão pela qual, ferido na sua dignidade de monarca (e pai), D. João V contrapõe um novo plano, mais ambicioso e opulento, agora, e que colhe, aliás, o beneplácito dos seus pares espanhóis: plano esse onde, obviamente, os arquitectos da Corte portuguesa teriam o papel principal e cuja execução ocuparia os meses de Maio a Setembro de 1728.

Ora, conserva o arquivo de Madrid, no mesmo fundo, um outro desenho relativo à função do Caia: desenho esse parcialmente legendado em português ("ponte"; "plano da casa"), mas que ostenta, igualmente, legendas castelhanas (acrescentadas), que afirmam peremptoriamente tratar-se do "Plano Perfil y Elevaziones que se ha dado por Portugal de la Casa que se ha de hazer sobre el Puente del Rio Caya"158. Mas, sobretudo, plano que se concilia integralmente com as descrições averbadas pelos memorialistas, desde logo no que respeita ao número de vãos (vinte duas janelas, além das portas axiais) e à presença dos anjos-fama nos cunhais, sendo obviamente comum (porque obrigatório) o aparato heráldico dos portais de acesso. Tudo indica, por conseguinte, ser este o projecto efectivamente realizado e onde, desse modo, caberia afinal à Corte portuguesa (e aos seus artistas) o papel principal, em consequência da peculiar gestão político-diplomática deste processo, também ele peculiar e da qual, com efeito, os aspectos estritamente artísticos não poderiam objectivamente dissociar-se, 
tendo em conta a efectiva inviabilidade prática de proceder a uma projecção conjunta da componente cenográfica das entregas. Alhures, na verdade, assentaria a repartição de esforços.

Mero - e um tanto rude - esboço de um projecto seguramente finalizado (cujos riscos, como de hábito, se terão consumido na efervescência do estaleiro), ilustra ele, com efeito, por intermédio de planta, alçados frontal e lateral e corte transversal da sala média, um recinto de maior monumentalidade e extensão (ampliado em cerca de um terço em relação ao projecto original espanhol), coberto de telhado único de quatro águas (por oposição aos três sucessivos do primitivo plano), ritmando-se os alçados laterais de pilastras jónicas engrinaldas, coroado o todo de platibanda balaustrada, ornada de urnas e flanqueada, nos cunhais, dos anjos-fama: tema esse interrompido apenas pelo frontão que, em cada topo, remata o portal de acesso, sobrepujado do aparato heráldico das duas Coroas, imprescindível na correcta observância da obsessiva égalité des deux parts que alimentaria, em toda a extensão, o programa cerimonial da troca das princesas. Somente detalhado (sumariamente), em amostra, na molduração de uma janela borrominiana, das pilastras que a flanqueiam e da balaustrada de remate e respectivas urnas, tal é suficiente, todavia, para afastar da sua programação a mão de Ludovice: seja na relativa secura da sua projecção (seguramente compensada pelos esplendores da execução do trompe l'oeil, tanto exteriormente como no décor interno da sala e meia que lhe competia), seja até no carácter geral da execução do esquisso, inconciliável com a sua consabida sensibilidade ao valor do ornato e defesa intransigente da majestade da composição.

Inversamente, esse academismo seco distingue justamente o que é possível apurar sobre a maneira particular de Canevari. Outro tanto se podendo dizer do seu gosto por certos recursos de composição, como é o caso do tópico das pilastras engrinaldadas da ordem jónica, que repercute como marca de água, da fachada, ainda romana, da Igreja dos Estigmas, aos primeiros trabalhos portugueses, como a torre da Universidade de Coimbra $^{59}$ ou as arquitecturas efémeras dos fogos de artifício que, em Lisboa, assinalariam, no início desse ano (enfim), a assinatura das capitulações matrimoniais: e onde, de igual modo, se divisa o tema imagético da $F \operatorname{sma}^{60}$. E talvez seja esse especial protagonismo na programação artística das sumptuosas entregas (que necessariamente abre outras frentes de investigação) a razão de fundo do protagonismo que, por seu turno, aparentemente tem (como já foi assinalado ${ }^{61}$ ) no próprio contexto cerimonial: em cuja lauda de Arquitectos efectivamente surge, com seu ajudante (decerto Nicolao Moribello, Genoves, que alberga em sua casa, na Rua Larga de S. Roque, na Páscoa desse ano $^{62}$ ), antes de Ludovice e do ajudante respectivo $0^{63}$ : situação a que, por seu turno (no óbvio confronto com o alemão), talvez não tenham sido alheias as vicissitudes que rodearam, encerrado o capítulo das entregas, a carreira portuguesa do romano...

Precedendo Canevari, todavia, nas estrita mesura protocolar das carruagens, outro nome avulta e merece reparo: o de Francisco Pereira da Fonseca, indicado por Natividade como o "sargento-mor e engenheiro da praça de Setúbal, que modelou a ponte sobre o rio Caia"64: e cujo posto, na estrutura corporativa oficial (de sargento-mor e engenheiro) Ihe justificaria uma óbvia precedência. Ora, são sintomaticamente silenciosas as fontes castelhanas sobre esta matéria, do mesmo passo que os cinco arcos de meio ponto sobre que assenta o projecto conhecido se não harmonizam com o que, actualmente ainda, pode observar-se. Observação essa, de facto, que comprova ser ela assente em três arcos abatidos, com seus talhamares e provida de tabuleiro reentrante em relação aos patins de acesso, claramente enquadrada, na verdade, no carácter da engenharia militar joanina e ilustrando, no essencial, obra de raiz, ainda que ostentando, nas entregas do lado castelhano (provavelmente por erosão das margens), claro reaproveitamento de estruturas anteriores.

Tudo se concilia, deste modo, para demonstrar que, em virtude da aceitação, por parte da Coroa espanhola, do projecto que $D$. João $V$ contrapõe (mais ambicioso ainda) ao original por ela elaborado (ilustrado no desenho conhecido), por efeito do repúdio da sua sugestão inicial de realização de obra rápida, susceptível de executar-se em vinte dias, a Portugal tenha cabido, nesta matéria, particular protagonismo, concentrando-se a participação espanhola no projecto hidráulico, de construção do dique e desmontagem do leito novo onde corria o Caia, que Bracamonte organizara. E assumindo a Corte lusitana, por intermédio de António Canevari e de Francisco Pereira da Fonseca a modelação, a um tempo da sumptuosa casa das entregas e da ponte sobre que havia de assentar: projecto que consubstanciaria a resposta altiva do monarca português às exigências de Isabel Farnésio.

Mas que Ihes dá expressão, seguramente (justificando, por essa via, a tranquila adesão do parceiro espanhol), ao propiciar a Mariannina um quadro ainda mais faustoso que o que contemplara na llha dos Faisões. $\mathrm{E}$ era por tudo isto que, de Madrid, o embaixador Abrantes podia justificadamente afirmar "que com razam estão todos em expectação de ver da nossa p. te o mais opulento, e lustrozo espectáculo, que jamais deu Portugal de sy". Programa esse, todavia, cuja reconstituição apenas o cabal conhecimento das vicissitudes em que se gerou 
permite hoje cabalmente reconstituir. Por isso que o quadro histórico se revela sempre fundamental ao conhecimento do processo artístico, que objectivamente determina: seja ele menos peculiar que o intrincado novelo político-diplomático em que houve que levar-se a efeito a troca das princesas.

\section{NOTAS}

${ }^{1}$ Efectivamente e pós longa controvérsia historiográfica, em que principalmente se empenharam, pela parte da primazia portuguesa na proposta, Alfonso DANVILA (Fernando VI y Doña Barbara de Braganza, 17131748, Madrid, 1905), RODRÍGUEZ VILLA (Revista de Archivos, Bibliotecas y Museos, tomo II, p. 192) e António de BALLESTEROS Y BERETTA (Historia de España y su influencia en la Historia Universal, 1918-1941, tomo V, p. 81) e, pela tese inversa, Caetano BEIRÃO, (Cartas da Rainha D. ${ }^{a}$ Mariana Vitória para a sua família de Espanha, Lisboa, 1936, pp. LXI-LXVI e Eduardo BRAZÃO, Relações externas de Portugal: Reinado de D. João $V$, Lisboa, 1937), seria a matéria cabalmente esclarecida por Maria Teresa BARRENECHEA ("Maria Barbara de Braganza, Princesa de Asturias", Eidos, n 4, Barranquilla, 1956, p. 33), dando afinal razão ao que, em seu tempo, haviam afirmado os cronistas lusos contemporâneos, D. António Caetano de SOUSA [História Genealógica da Casa Real Portuguesa, Lisboa, 1741,

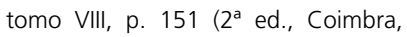
Atlântida Editora, 1951)] e Frei José da NATIVIDADE (Fasto de Hymeneo, Lisboa, 1752, pp. 4-5). A proposta, com efeito, teria por ponto de partida uma comunicação do secretario de Estado de Filipe V de Espanha, Grimaldi, ao embaixador em Lisboa, Capecelatro, datada de 12.04.1725. Na verdade, logo em inícios do mês, a própria Rainha Isabel de Farnésio comunicava ao Papa, a par da notícia do repúdio, a sua intenção de "casar á mi primogénito [metaforicamente: tratava-se do enteado-herdeiro, o Príncipe das Astúrias] en Portugal, y mi hija con el Prín- cipe hijo del citado Rey [D. João V], en lo que tenderé grandissimo placer, tanto por estar mal con Francia, como por contar aliados para cualquier medida que pudiera adoptarse contra mi" (A. DANVILA, ob. cit., p. 43).

${ }^{2}$ Cfr. TAXONERA, Luciano de, Isabel de Farnesio. Retrato de una Reina y perfil de una mujer (1692-1766), Barcelona, Editorial Juventud, S. A., 1943, pp. 108-109.

${ }^{3}$ Ob. cit., pp. 96-97.

${ }^{4}$ Sobre este episódio veja-se, em síntese, BEIRÃO, C., ob. cit., pp. LIIILIV e LXVIII-LXXI.

${ }^{5}$ Cfr. DANVILA, A., ob. cit., pp. 45-47, 49-51 e 59; BEIRÃO, C., ob. cit., pp. LXXII-LXXVII e LXXXII-XCIV; BARRENECHEA, M. T., ob. cit., p. 34; NATIVIDADE, F. J. da, ob. cit., p. 6; SANTARÉM, Visconde de, Quadro elementar das relações politicas e diplomáticas de Portugal, vols. 2, Paris, 1842, pp. 189 e 195 e MARTINEZ, Pedro Soares, História Diplomática de Portugal, Lisboa, Editorial Verbo, 1992, p. 188.

${ }^{6}$ Cfr. PIMENTEL, António Filipe, Arquitectura e Poder: o Real Edifício de Mafra, Lisboa, Livros Horizonte, 2002, pp. 29-31.

${ }^{7}$ Cfr. SOUSA, D. A. C. de, ob. cit., tomo 8, pp. 151-152; NATIVIDADE, Fr. J. da, ob. cit., pp. 8-11; DANVILA, A., ob. cit., pp. 53-54; BEIRÃO, C., ob. cit., pp. XCII-XCIV; BARRENECHEA, M. T., ob. cit., p. 37; TEDIM, José Manuel, "O triunfo da festa barroca. A Troca das Princesas", Arte Efémera em Portugal, Cat., Lisboa, Fundação Calouste Gulbenkian, 2000, p. 175 e GÓMEZ URDÁÑEZ, José Luís, Fernando VI, Madrid, Arlanza Ediciones, 2001, p. 29.

${ }^{8}$ Cfr. NATIVIDADE, Fr. J. da, ob. cit., pp. 14 e DANVILA, A., ob. cit., pp. 59-60.

${ }^{9}$ Cfr. BEIRÃO, C., ob. cit., pp. XCIX-CX; DANVILA, A., ob. cit., p. 56 e GÓMEZ URDÁÑEZ, J. L., ob. cit., p. 29.

${ }^{10}$ Cfr. SOUSA, D. A. C. de, ob. cit., pp. 191-195 e 214-218; NATIVIDADE, Fr. J. da, ob. cit., pp. 17, 36 e 118; DANVILA, A., p. 59-61 e 74-75; BEIRÃO, C., ob. cit., pp. CIX-CXIV; BARRENECHEA, M. T., ob. cit., pp. 3741; TEDIM, J. M., ob. cit., pp. 175176; GÓMEZ URDÁÑEZ, José Luís, pp. 29-30 e CASSOTTI, Marsilio, Infantas de Portugal, Rainhas em Espanha, Lisboa, A Esfera dos Livros, 2007, p. 253.

${ }^{11}$ Cfr. GÓMEZ URDÁÑEZ, J. L., ob. cit., p. 31.

$$
\begin{aligned}
& { }^{12} \text { Cfr. DANVILA, A., p. } 59 \text { e nota } \\
& { }^{13} \text { NATIVIDADE, Fr. J. da, ob. cit., } \\
& { }^{14} \text { Cfr. Boletim da Academia }
\end{aligned}
$$
(3). p. 247 Nacional de Belas-Artes, tomo I, 1935, pp. 22 e 25.

${ }^{15}$ Cfr. NATIVIDADE, Frei. J. da, ob. cit., pp, 67, 78, 88; TEDIM, J. M., ob. cit., pp. 177 e 192; CORREIA, Ana Paula Rebelo, "Fogos de artifício e artifícios de fogo", Arte Efémera em Portugal, Cat., Lisboa, Fundação Calouste Gulbenkian, 2000, pp. 123128; PIMENTEL, António Filipe, "Ascensão e queda de António Canevari: reflexões sobre um problema historiográfico" (no prelo).

${ }^{16}$ Cfr. SOUSA, D. A. C. de, ob. cit., pp. 215-218; NATIVIDADE, Fr. J. da, ob. cit., pp. 119-120.

${ }^{17}$ Cfr. DANVILA, A., ob. cit., pp. 74-75; VOLTES, Pedro, La vida y la época de Fernando VI, Barcelona, Ediciones Planeta, 1998, pp. 43-45.

${ }^{18} \mathrm{Cfr}$. VOLTES, P. , ob. cit., p. 45. 

75.

${ }^{19}$ Cfr. DANVILA, A., ob. cit., p.

${ }^{20}$ Cfr. GÓMEZ URDÁÑNEZ, J. L., pp. 31-32.

${ }^{21}$ Cfr. NATIVIDADE, Fr. J. da, ob. cit., p. 134: VITERBO, Sousa, Dicionário histórico e documental dos arquitectos, engenheiros e construtores portugueses, Lisboa, INCM, 1988, vol. III, pp. 41-42.

${ }^{22}$ Cfr. SANTARÉM, V. de, ob. cit., tomo V, p. 244.

${ }^{23}$ Cfr. GÓMEZ URDÁÑEZ, J. L., p. 32.

${ }^{24}$ Cfr. BARRENECHEA, M. T., ob. cit., p. 43.

${ }^{25}$ Cfr. DANVILA, A., pp. 88-89; TAXONERA, L., p. 169; BEIRÃO; C., ob. cit., pp. CXXII-CXXIV; GÓMEZ URDÁÑEZ, J. L., pp. 30-31; VOLTES, P., pp. 51-52

${ }^{26}$ Cfr. NATIVIDADE, Fr. J. da, ob. cit., p. 139.

${ }^{27}$ Cfr. BEIRÃO, C., ob. cit., p. CXXVI.

${ }^{28}$ Cfr. NATIVIDADE, Fr. J. da, ob. cit., pp. 198-199.

${ }^{29}$ Cfr. BEIRÃO, C., ob. cit., p. CXXV. Veja-se tb. PÉREZ CAMINERO, Ramón, Bodas reales en Badajoz: "Bárbara de Braganza - Fernando de Borbón", Reyes de España, 1746-1758/59. Documentos del Archivo Histórico Provincial de Badajoz, Badajoz, Junta de Extremadura, 2003, p. 60.

${ }^{30}$ Veja-se, sobre este aspecto (de parte a parte) e o trajecto da jornada: NATIVIDADE, Fr. J. da, ob. cit. (prólogo) e pp. 105, 109-110, 140-146, 155, 162, 165, , 169-172, 174, 180, 189-190, 192-197, 204-215, $217-$ 226; SOUSA, D. A. C. de, ob. cit., tomo VIII, pp. 152-157; DANVILA, A., pp. 92-93; BEIRÃO, C., ob. cit., pp. CXXVI-CXXXII; BARRENECHEA, M. T., ob. cit., pp. 46-48.

${ }^{31}$ Cfr. MONTGON, Charles Alexandre de (Abade de), Mémoires de Monsieur l', Lausanne, 1750, p. 106 (trad. port. "Do Caia ao Paço da Ribeira", CHAVES, Castelo Branco, Portugal nos séculos XVII e XVIII, quatro testemunhos, Lisboa, Lisoptima, 1989). A opinião é, de resto, corroborada por outras fontes: cfr. DANVILA, A., ob. cit., p. 96 e PÉREZ CAMINERO, R., ob. cit., pp. 62-63 e 115.

${ }^{32}$ Cfr. ob. cit., p. 106.

${ }^{33}$ Veja-se: SOUSA, D. A. C. de, ob. cit., tomo VIII, pp. 157-163; NATIVIDADE, Fr. J. da, ob. cit., pp. 227242, 277-278 e 284-285; DANVILA, A., ob. cit., pp. 93-96; BEIRÃO, C., ob. cit., pp. CXXXIII-CXL; BARRENECHEA, M. T., ob. cit., pp. 49-54; PÉREZ CAMINERO, R., ob. cit., p. 61.

${ }^{34} \mathrm{Cfr}$. TEIXEIRA, José de Monterroso, "Arte, representação e espectáculo: o programa artístico e os festejos da "troca das princesas" em 1729", Festa Barroca a Azul e Branco, Cat., Lisboa, Fundação Ricardo Espírito Santo Silva, 2002, p. 55. A verba, contudo, terá de imputar-se à empresa no seu conjunto, incluídas as construções, adereços e logística e não somente ao pavilhão do Caia, como defende o autor.

${ }^{35}$ Vejam-se: LOZANO BARTOLOZZI, Maria del Mar, "Festejos y retórica: las capitulaciones de las bodas reales celebradas en Caia el año 1729", El arte en las cortes europeas del siglo XVIII, Madrid, Comunidad de Madrid, 1989; PIZARRO GÓMEZ, Francisco Javier, "Doña Bárbara de Braganza y el fausto cortesano en las fiestas reales", Portugal e Espanha entre a Europa e Além-Mar, IV Simpósio Luso-Espanhol de História da Arte, Coimbra, 1992.

${ }^{36} \mathrm{Cfr}$. TEDIM, José Manuel Alves, Festa régia no tempo de $D$. João $V$. Poder, espectáculo, arte efémera, diss. Doutoramento, Porto, Universidade Portucalense Infante D. Henrique, 1999, vol. 1, pp. 288-311.

${ }^{37} \mathrm{Cfr}$. idem, ibidem, vol. 1, pp. 291 e 301-302.

${ }^{38}$ Cfr. NATIVIDADE, Fr. J. da, ob. cit., pp. 165-166.

${ }^{39}$ Cfr. TEDIM, J. M., ob. cit., vol. 1, p. 301

${ }^{40}$ Cfr. Veja-se TEIXEIRA, José de Monterroso, O Paço Ducal de Vila Viçosa. Sua arquitectura e suas colec- ções, Lisboa, Fundação da Casa de Bragança, 1983, pp. 95-103.

${ }^{41}$ Cfr. NATIVIDADE, Fr. J. da, ob cit., pp. 198-199. Veja-se tb: SOUSA, D. A. C. de, ob. cit., tomo VIII, pp. 154-155; BEIRÃO, C., ob. cit., pp. CXXVIII-CXXIX.

${ }^{42}$ Cfr. NATIVIDADE, Fr. J. da, ob. cit., pp. 197-203; FERRÃO, Leonor, "Custódio Vieira", PEREIRA, José Fernandes (dir.), Dicionário da Arte Barroca em Portugal, Lisboa, Presença, 1989, p. 522.

${ }^{43}$ Cfr. MECO, José, "Tectos", Do Palácio de Belém, Cat., Lisboa, Presidência da República, 2005, pp. 415421; ESPANCA, Túlio, Inventário Artístico de Portugal, VIII, Distrito de Évora (concelhos de Arraiolos, Estremoz, Montemor-o-Novo, Mora e Vendas Novas), Lisboa, Academia Nacional de Belas-Artes, 1975; COELHO, António Borges, MARQUES, Gustavo, Vendas Novas, história e património, Vendas Nvas, CMVN, 1991.

${ }^{44} \mathrm{Na}$ verdade, segundo a informação fornecida por Fr. J. da NATIVIDADE, "Havia [no palácio] sete quartos de três cazas cada hum, mui ricamente adereçados para a accomodação do Emminentissimo Cardeal, D. Nuno da Cunha e Ataíde, e do Senhor Patriarca D. Thomas de Almeida. Pelo que respeitava ao estado do Sereníssimo Príncipe do Brazil, e da Senhora Princeza das Astúrias, tinha cada hum destes dous Senhores, neste luzidissimo Palácio, Casa de docel, gabinete, e câmara. As Officinas, e tudo mais pertencente ao serviço da Magestade da Senhora Rainha, cahia para a parte esquerda do Palácio" (ob. cit., pp. 197 e 200). Contudo, o cronista compõe a sua obra a anos de distancia, com base na memória e no conhecimento teórico fornecido pela "planta que temos em nossa mão". E sabe-se, v.g. que o Patriarca D. Tomás seguiria caminho diverso e não pernoitaria no palácio. Ora, apenas nas dependências ao lado esquerdo do átrio (em correspondência aos aposentos superiores do Rei — situação que se deduz 
por sabermos que os da Rainha se situavam na parte esquerda) se conservam tectos pintados, aliás mais rudes na pintura e, como fica dito, sumariamente acabados. Assim e após o que se sabe sobre o desenvolvimento do processo da troca das princesas e da precipitada decisão de trasladar à fronteira as duas cortes, é possível que apenas estivesse prevista a decoração dos aposentos superiores, destinados aos príncipes, improvisando-se depois, na sequencia da necessidade de alojar os Reis, novo aposento no piso térreo com esse destino. Este, deverá ter sido ocupado na ida por Bárbara e no retorno por D. José, uma vez que Mariannina, atendendo à sua idade, partilharia por anos cómodos imediatos aos aposentos da Rainha, o que facilitaria a distribuição.

${ }^{45}$ Cfr. TAXONERA, L. de, ob. cit., p. 169
${ }^{46} \mathrm{Cfr}$. idem, ibidem; BARRENE-

CHEA, M. T., ob. cit., p. 44.

${ }^{47}$ Vejam-se supra notas 10 e 11.

48 Archivo Histórico Nacional, Madrid, Estado, 754.

${ }^{49} \mathrm{Cfr}$. BARRENECHEA, M. T., ob. cit., pp. 44-45.

${ }^{50} \mathrm{Cfr}$. idem, ibidem, p. 45.

${ }^{51} \mathrm{Cfr}$. idem, ibidem, p. 238.

${ }^{52}$ Triunfo Elvécio, BME, Ms. 3203 3205 (TEDIM, J. M., Festa Régia..., pp. 315-317).

${ }^{53}$ Cfr. PÉREZ CAMINERO, R., ob. cit., p. 78.

54 Archivo Histórico Nacional, Madrid, Estado, 754.

${ }^{55}$ PIZARRO GÓMEZ, Javier, "Doña Bárbara de Braganza...", p. 69. Vejase tb. TEDIM, J.M., "O triunfo da festa barroca...", pp. 180-182.

${ }^{56}$ Cfr. PIMENTEL, A. F., "Ascensão e queda de António Canevari...".
${ }^{57}$ Cfr. idem, ibidem.

58 Archivo Histórico Nacional, Madrid, Estado, 2461 - 1.

${ }^{59}$ Cfr. PIMENTEL, António Filipe, "António Canevari e a Torre da Universidade de Coimbra, Artistas e Artífices e a sua mobilidade no mundo de expressão portuguesa, Actas, VII Colóquio Luso-Brasileiro de História da Arte, Porto, Faculdade de Letras da Universidade do Porto, 2005, pp. 4958.

${ }^{60} \mathrm{Cfr}$. PIMENTEL, A. F., "Ascensão e queda de António Canevari...".

${ }^{61}$ Cfr. TEIXEIRA. J. M., ob. cit., p. 60.

${ }^{62} \mathrm{Cfr}$. CARVAlHO, Ayres de, D. João $V$ e a arte do seu tempo, Lisboa, 1962, vol. II, p. 368.

${ }^{63}$ Cfr. NATIVIDADE, Fr. J. da, ob. cit., p. 180.

${ }^{64} \mathrm{Cfr}$. idem, ibidem. 